\title{
هل هن قصدية وراء تغييب أعلام واسط في كتاب ربيع الأبرار للززهشري؟
}

الباحثْ صالح الطائي

واسبط/ العرأ

الاقدهمة

حينما جئت و اسط، وجدت أهلها نجوما، ولكنها تكاد تخشى السطوع، فسألت منققيهم عن سبب كونهم شبه مغمورين، وكانو ا كأنهم قد اتفقو ا على جو اب و احد؛ وهو أن قرب و اسط من بغداد جعل بغداد تسرق ألقها،

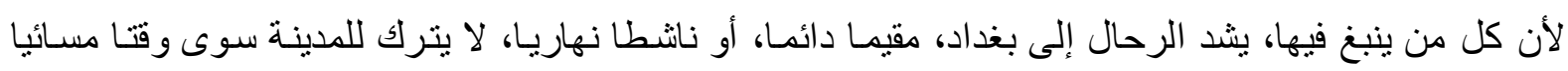
للأكل و النوم، والظاهر أن هذا هو حال هذه المدينة الوادعة على مر التاريخ، فقد سبق و أن وضعتُ كتابا بعنوان "رجال البصرة في كتاب ربيع الأبرار للزمخشري"، بلغ عدد من أحصيت ممن ذكر هم الزمخشري أكثر من هن أربعمائة علم بصري، وبعدها أجريت جردا لرجال الكوفة فيه عسى أن أكتب عنهم في مناسبة تتطلب ذكر هم، فوجدتهم بحدود الثلاثمائة أو أقل قليلا، وكم كانت دهشتي بل صدمتي كبيرة وأنا حتى مع كثير البحث و التدقيق،

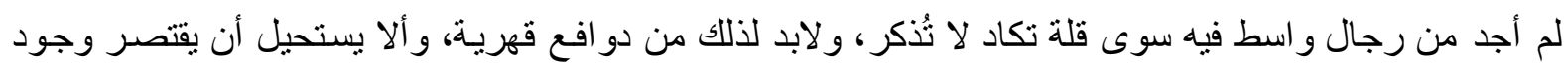

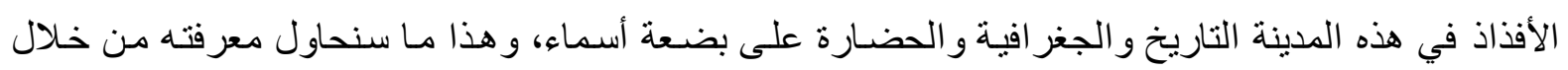

البحث.

أسميت بحثي "هل من قصدية وراء تغييب أعلام واسط في كتاب ربيع الأبر ار للزمخشري؟"، وقسمته

على ثلاثة محاور، و اتبعت في كتابته المنهج الوصفي لكونه أسلوبا من أسـاليب التحليل المرتكز على معلومـات كافية ودقيقة عن ظاهرة أو موضوع محدد، ومن خلال مدة زمنية معلومـة، وذلك من أجل الحصول على نتائج

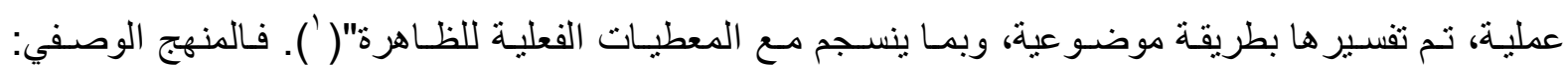
"طريقة لوصف الموضوع المر اد دراسته من خلال منهجية علمية صحيحة، وتصوير النتائج التي ينم التوصل إليها على أثكال رقمية معبرة يمكن تفسير ها"( r). من هنا وجدته أصلح المناهج للكتابة عن مثل هذه المواضيع. و اعتمدت في كتابته بعض أوثق المصادر التاريخية.

المهور الأول - هدينة وبان وكاتب وكتاب

تلتقي في مطاوي هذا المحور عدة ثيمات رئيسية، الأولى: المدينة التي ارتبط بها من سنتحدث عنهم

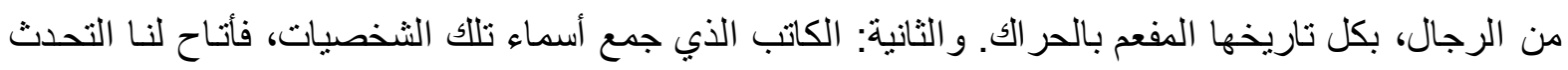
عنهم. و الثالثة: الكتاب الذي انطوت صنحاته على شذر ات من أقو الهم و أفعالهم، فكانت النواة التي دار حولهاء حديثنا. وثثمة ثنانوية تمثل الو الي الذي بنى مدينة واسط التاريخية على أنقاض آثار الحضارة العر اقية القديمة. و اسط المدينة. أما المدينة (و اسط)( (َ) فإن مـا كتب عنها قديما وحديثا يغني عن إعادة مـا قيل. لكن لابد من التتويه إلى أن المدة بين بناء الكوفة و البصرة وبناء و اسط لم تكن بعيدة، فنصف قرن من الزمان ليس بالفارق

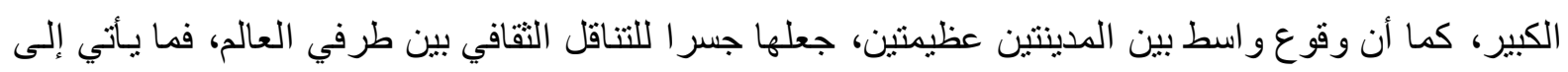


البصرة من العالم، فتنقله البصرة إلى بغداد أو الثـام أو الكوفة، يمر عبر واسط. وما يأتي إلى الكوفة من أنحاء

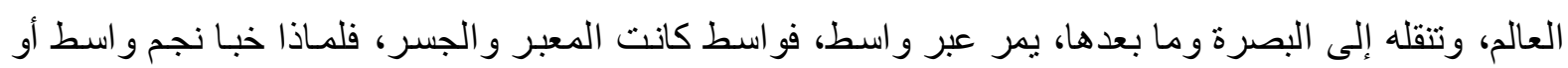

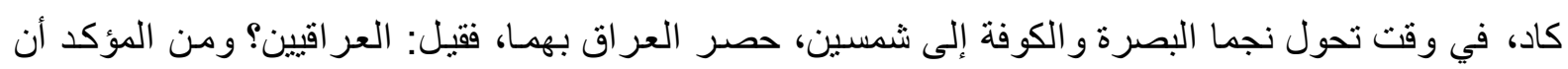
لذلك سبب، فما تبدو عليه واسط لا يمثل حقيقتها التاريخية، إلا إذا ما كان هناك تغييبا مقصودا. إن الظروف التي دفعت المسلمين إلى بنـاء العر اقين هي نفسها التي دفعت الحجـاج لبنـاء واسط فمن المؤكد أن مهمة عنبة بن غزوان لم تكن مدنبة، بمعنى أنه لم يُرسل إلى البصرة ليعمر هـا، ويشيد فيها المسـاكن

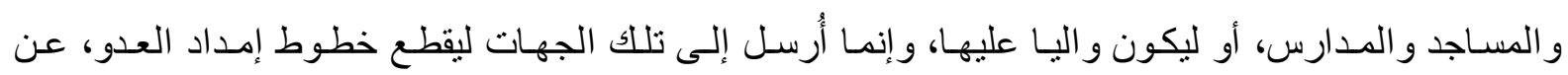
الثعبي، فال: "قُتل مِهر ان سنة أربع عشرة، فقال عمر لعتبة: قد فتح الله على إخوانكم الحيرة ومـا حولها، وقُّل عظيم من عظمائها، ولست آمن أن يمدهم إخو انهم من أهل فارس، فإني أريد أن أوجهك إلى أرض أرضع الهند لتمنع

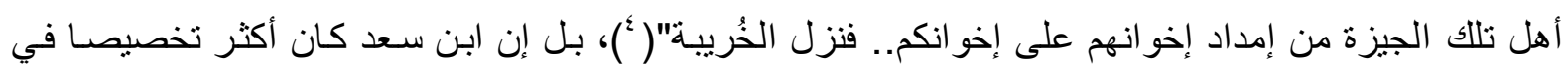

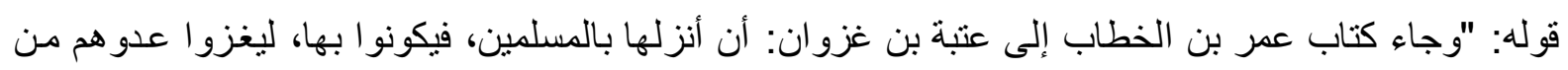

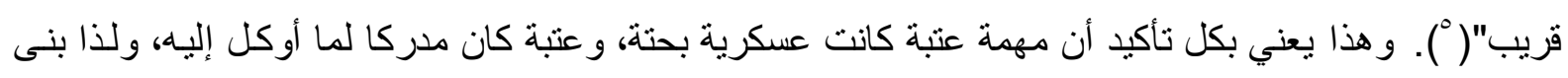
بعض المنشآت الضرورية له ولجنده من القصب، ولم يبنها بالطين أو الحجارة!

يفهم من هذا أن مـا قام بـه عتبة ليس أكثر من عملية تبديل، تبديل واقع البصرة القديمة من طابعها المدني البسيط؛ الذي يناسب طبيعة تلك العصور، ومـا كان عليه الإنسـان في تلك الدهور، إلى و اقع عسكري حربي قتالي، صدف و إن تمدن بعد ذلك بفعل الموروث و التطور و التبدل، لينزع ثوب العسكر اتية( ل)، ويرتدي

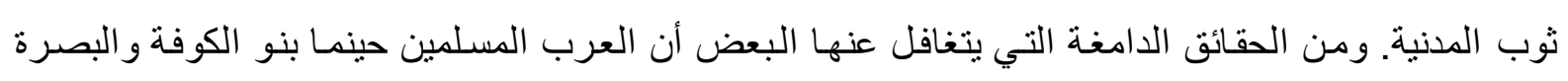
وو اسط وسامر اء و غير ها، لم يكونو ا يبحثون عن أماكن لسكن شعوبهم لأن أرضهم ضـاقت بهم مثنلا، وهم غالبـا

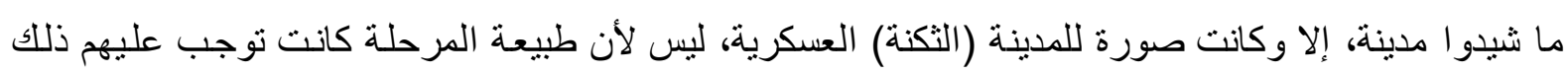

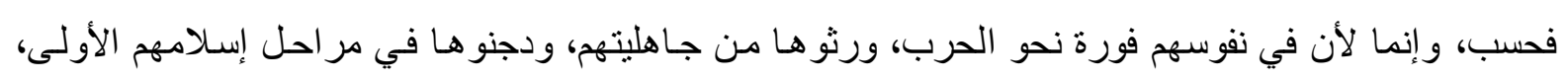
بعد عصر البعثة.

\section{سمر البناs}

عن جعفر بن موسى بن مرزوق الواسطي، قال: قدم علينا بو اسط رجل وصفته، قال: كنت خادم أنس

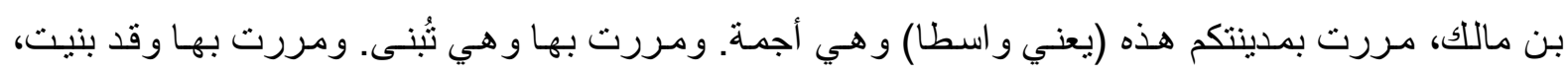

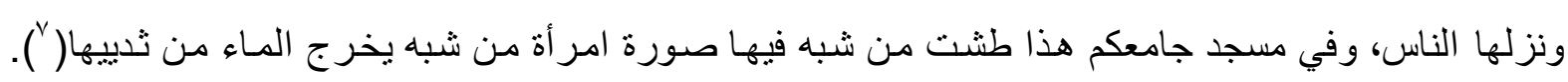
و هذه صورة عن بذخ واسط في بداية بنائها، تدل على البطر الكبير!

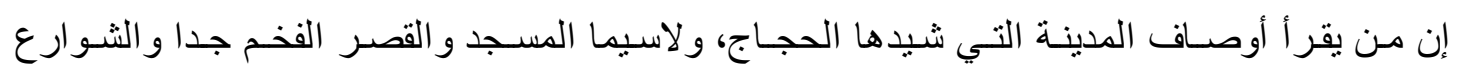

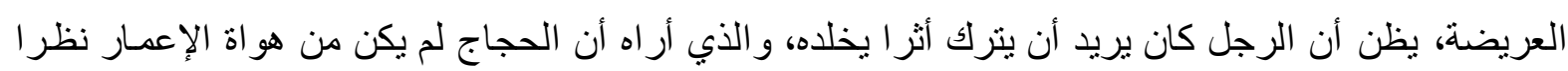

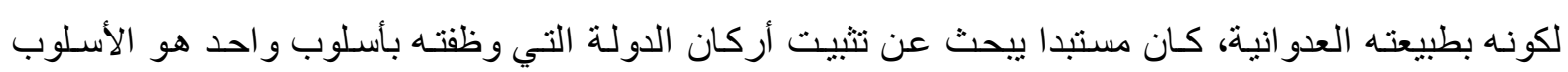


الافتر اسـي؛ الذي بدا واضحا في إخمـاده لثورة محمد بن عبد الرحمن بن الأشـعث، وفي عدد من وجدوهم في سجونه من النساء و الرجال الأبرياء.

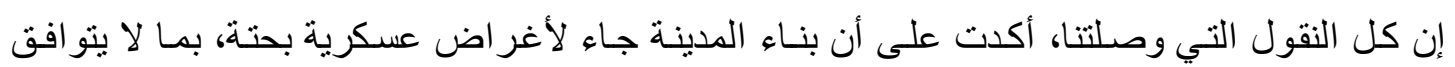

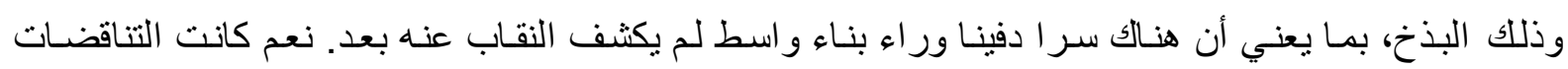
تجنمع في شخصية الحجاج، وقد جاء في الأثر : "خطب الحجـاج فقال: إن الله أمرنـا بطلب الآخرة وكفانـا مؤونـة

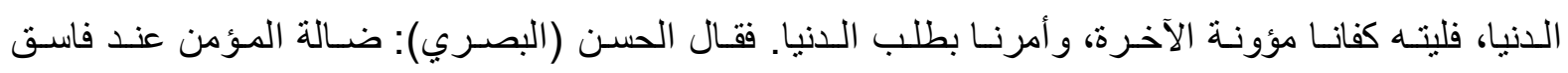
فليأخذها"( ^). و هذا ما قد يتخذه البعض سببا لبنـاء هذه المدينة، ولكن ذلك لا يشفي الغليل أبدا، فالطبع يغلب

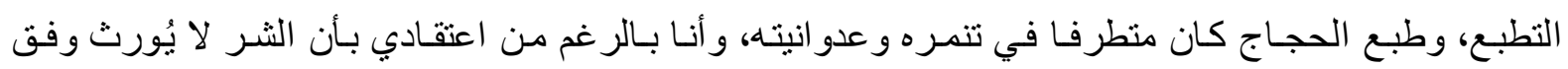
مفاهيم الور اثنة الجينية، وإن كانت هنالك رو ايات وأحاديث تؤكد وجود التوارث في منثل هذا النمط من السلوك، ونه إلا أن ما قام به حمحد بن يوسف الثقفي أخو الحجاج، يوم استعمله الحجاج و اليا على صنعاء يكاد يخالف منطوق

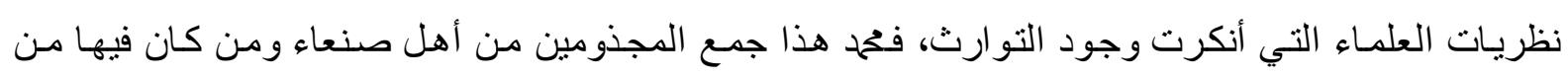
المجذومين، وجمع لهم الحطب ليحرقهم، فمات قبل ذلك( (9). بمعنى أن طبيعة ونشأة الحجاج و اندفاعه الكبير في دعم الأمويين إلى درجة أنه رجح فضل زيارة الخليفة في الثـام على زيارة بيت الله الحرام، نُظهر أنه لم يكن

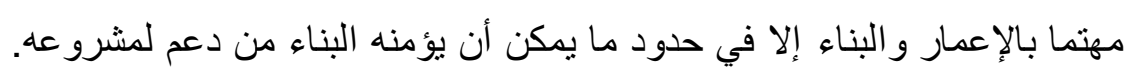

الكاتب

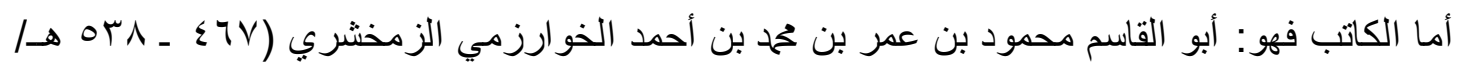

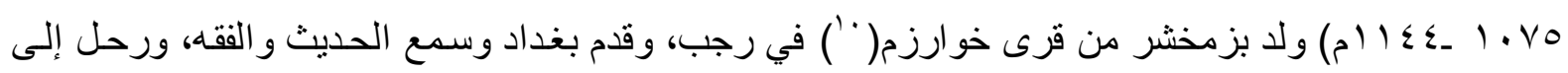

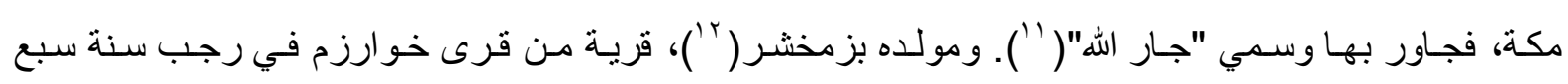

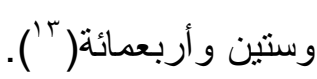

الزمخشري كان معتزلي الاعتقاد، وقد أكد ذلك عدد كبير من الكتاب و المؤرخين؛ منهم الصفدي في الكثكول، في قوله: ومن المعتزلة الصاحب بن عباد، و الزمخشري، و الفر اء النحوي(؛ُ أ) علما أنه وفد من ناحية يطغى على أهلها مذهب الاعتز ال، وربمـا لهذا السبب نشـأ متحمسا للاعتز ال، مجاهر ا بـه، فقد كان إذا قصد

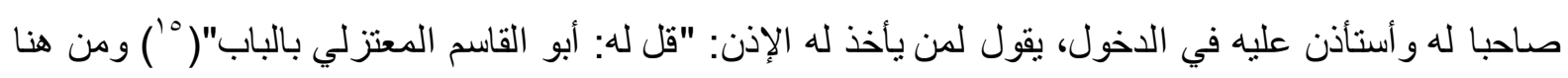

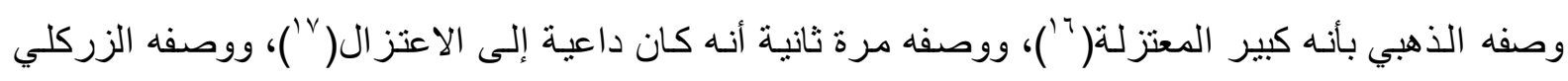

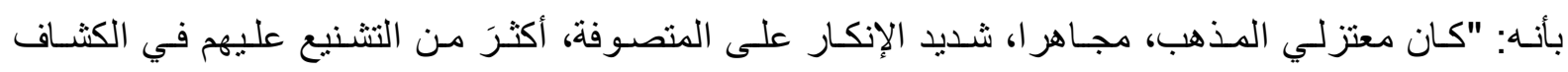

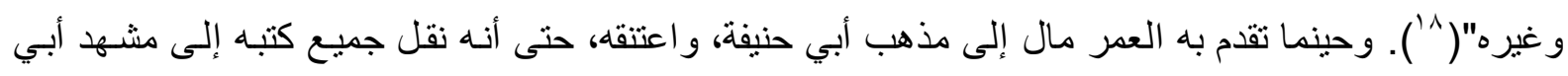
حنيفة، ووققها عليه"(9 (1) وقد يكون لمعتقده بصورتيه الأولى و الثانية أثرا على اختيار اته لمـادة كتابه، ولهذا أكثر من ذكر رجال البصرة لكثرة ما فيها من المعتزلة، ومن ذكر رجال الكوفة لكثرة مـا فيها من أنباع أبي حنيفة،

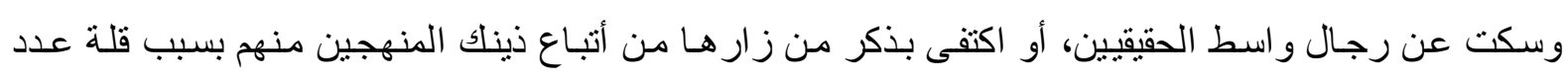
المعتزلة و أتباع أبي حنيفة في و اسط! 
و احد من الكم الكبير من مصنفات الزمخشري؛ هو كتاب: "ربيع الأبرار ونصوص الأخبار" الذي قال عنه كاتبه في المقدمة: "هذا كتاب قصدت بـه إجمام خو اطر الناظرين في الكثـاف عن حقائق التنزيلـ وترويح قلوبهم المتعبـة بإجالـة الفكر في اسـتخر اج ودائع علمهـ وخبايـاه، و التنفيس عن أذهـانهم المكدودة باستيضـاح

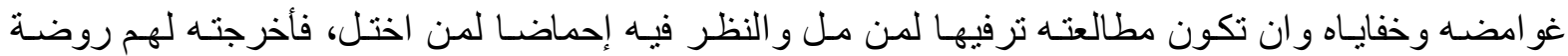

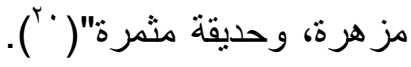

إذا هو كتاب للترويح عن النفس، وللتأديب وتقديم النصح من خلال ذكر النصوص و القصص المنسوبة إلى قائليها، فهو كتاب شعر وتاريخ و أدب و أصناف من العلوم الأخرى، وليس كتابـا يهتم بـالتراجم أو السير أو التاريخ، بمعنى أن الأسماء التي وردت فيه لا يمكن أن تقتصر على مدينة أو بلدة بعينها، و لا على اختصـاص

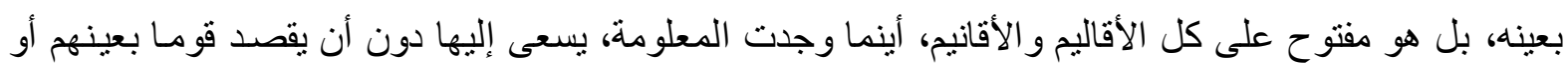
علما بعينه، ولكن الزمخشري اختار عادة ما يو افق معتقده، و أغفل ذكر غيره إلا ما ندر، ومن هنا قل حديثه عن رجال و اسط الذين لم تكن نربطه بهم رابطة معتقد.

إن اعتنـاق البلاذري لعقيدة الاعتز ال، وتتـدده في ذلك، فضـلا عن شـيوخه الذين أخـذ عنهم وعـن

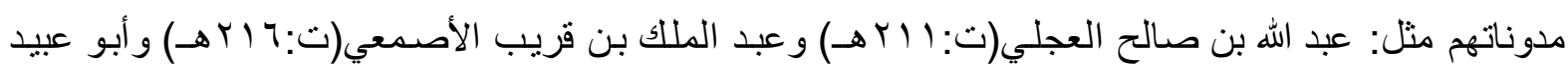

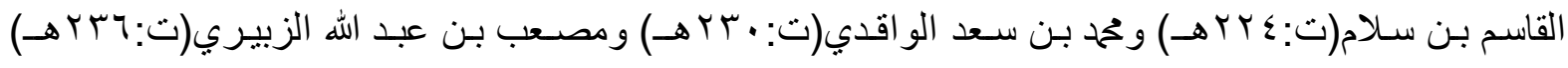

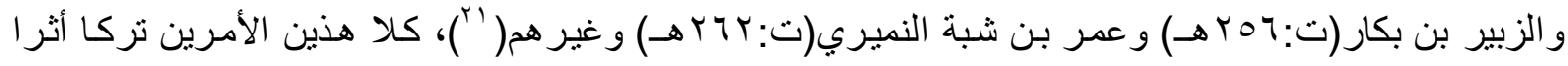

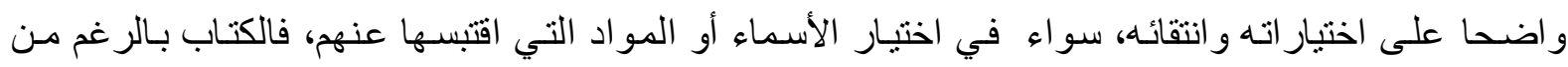
كونه يبدو في ظـاهره بعيدا عن المماحكات التحزبيـة، إلا أن مضمونه الذي يكاد يصب في اتجاه و احد، مـع استبعاد و اضـح للجو انب الأخرى، يُظهر وجود القصـية و التحزب فيـا!. فقد كـان الزمخشري حريصـا على الانتقاء مـن القريبين لمنهجيـه الخـاص و العـام، فهو مـع كونـه لــ يقتصـر على المـوارد البغداديـة القريبـة منــهـ للحصول على معلومات كتبه الكثيرة، قام برحلات عديدة إلى بلاد الجزيرة الفراتية، ومدنا عر اقية، وبلاد الثـام للبحث عن المعلومة. ولذا نجده قد نوع موارد كتبه من مختلف المدن ومن مختلف التخصصـات و الأصناف،

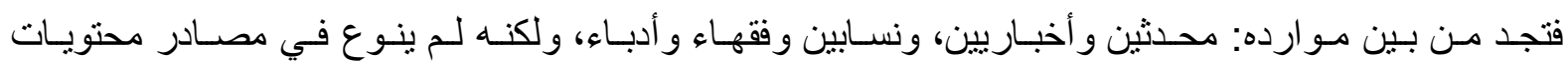
ومضمون الكتاب، فأبقى الكتاب موقوفا بشكل شبه كامل على فئة بعينها، دون مكونـات الإسـام الأخرى، إلاه المم!.

و أنـا و اقعـا لا أبغي اتهام الزمخشري جز افا، فربما لم تكن له قصدية في الاختيار، و ان مـا نجده في الكتاب من قصدية سببه أن الكتاب وقع مثنل غيره مـن نتاج الأقدمين بين أيسادٍ لئيمة، بـدلت وغيرت ورفعت وخفضت فيه، و هي التي تسببت في حدوث هذا التباين و التغابن، و هناك دلائل على وجود التلاعب، فالمعروف أن الزمخشري توفي سنة یبه للهجرة، بينما نجد في كتابه ربيع الأبرار معلومة عن فضل الله العمري الشـافعي

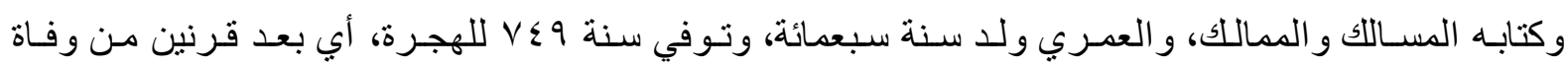


الزمخشري، وهذا لوحده يثبت وجود التلاعب، ويؤكد أن الكثبر من كتب تاريخنا تعرضت إلى أنواع كثبرة من التحريف لأسباب سباسية ومذهبية و عصبية.

إن وجود معلومة العمري يثبت أنه لابد وان تكون هنالك الكثير من الإضافات و التحريفات الأخرى التي

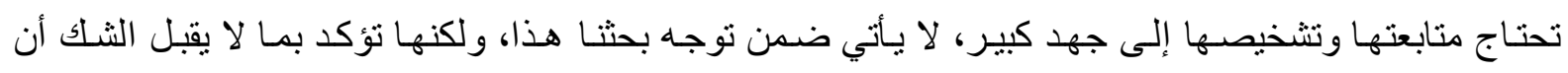

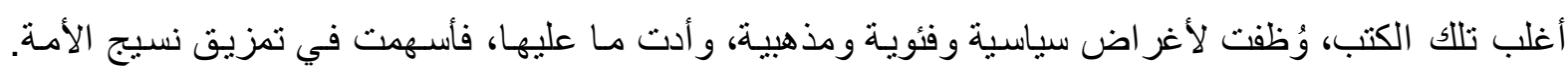

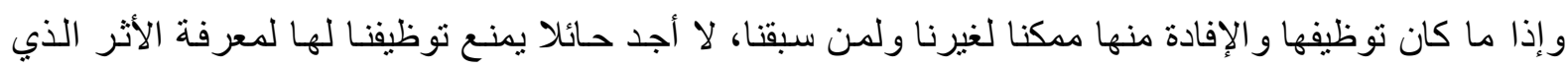

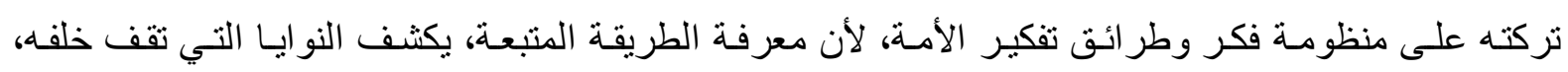

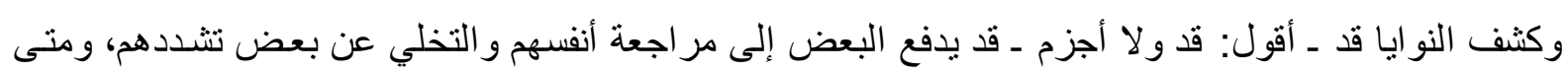
ما تخلى الإنسان عن التشدد ممكن أن تبدر منه إثـار ات قبول إيجابية، تشجع على التقرب منه و الحديث معهد

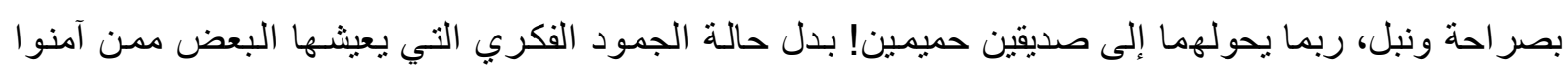
بالجزمية اللادحضية أو ما يسمى بالقطعية أو الوثوقية( (r)، وبالرغم من اختلاف وكثرة المسميات إلا أنها تعني الانغلاق الفكري على مفاهيم محددة: دينية أو فلسفية أو أدبية أو اقتصـادية أو حتى علمية مجردة. و الدو غمائيين

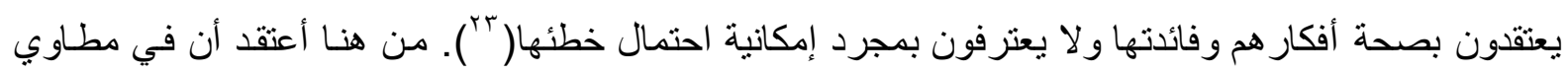
ربيع الأبر ار يكمن سر تغييب رجال واسط، والتأكيد على غير هم من رجال الأقاليم الأخرى!.

\section{المهور الثاني - الرجال والبغرافية}

لتأكيد من وجود القصدية من عدمها، سو اء من المؤلف أو من قبل غيره؛ ور اء تغييب رجال واسط، ولكي لا نتهم بأن رأينا تأثر بضغوط نظرية المؤامرة، سنحاول التحدث بايجاز عن تر اجم الرجال الذين وردت

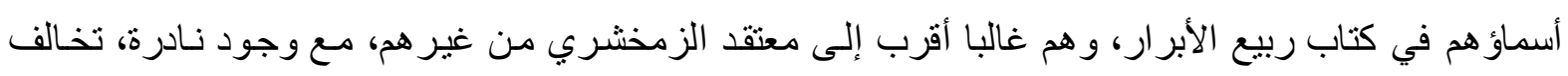
منهجه العام، مثل حديثه عن دعبل الخزاعي و السبد الحميري. وسنقف بداية عند المدن التي ورد ذكر هـا فيه، مهيه

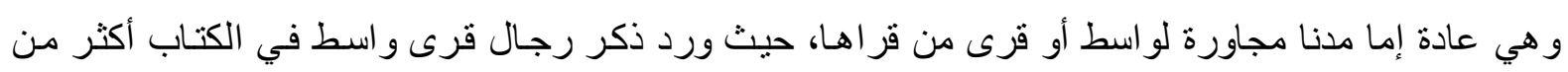
ذكر رجال المدينة نفسها. مع أن مجرد وجود مثل هؤلاء الرجال الأعلام في ريف مدينه ما، يؤكد وجود من هم

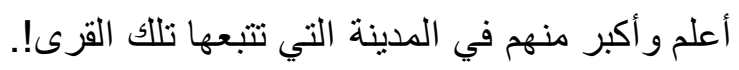

إن من الدلائل على تطور و اسط تقافيا واقتصـاديا وزر اعيا النص الذي أورده الزمخشري عن مدينة كسكر،؛ التي كانت مشهورة بتسمين الاجاج إلى أحجام بصعب الوصول إليها في هذا العصر، وهو نص مد مده

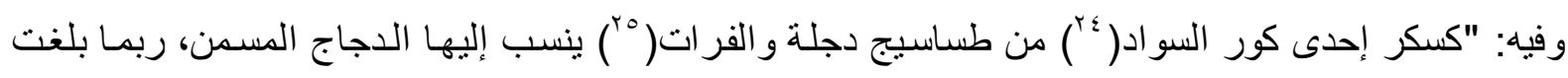

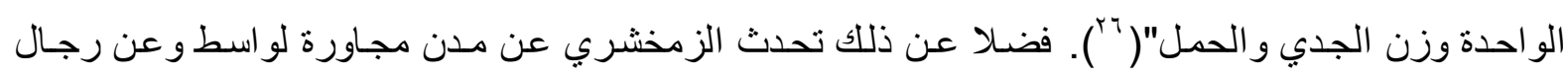
قر اها، ومن ذلك حديثه عن ميسان، في قوله: "بلغ عمر أن عامله بدست ميسان، قال:

$$
\text { إذا كنت ندماني فبالأكبر اسقني لا تسقني بالأكبر المثلم }
$$

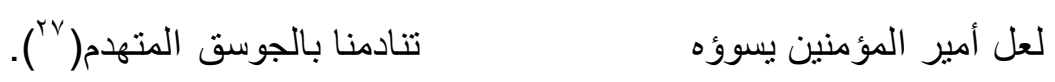




\section{و ميسان: كورة واسعة كثيرة القرى و النخل، بين البصرة وو اسط، قصبتها ميسان(ب^).}

ثم تحدث عن ذي قار، قال: قال ابن عباس: "دخلت على علي بذي قار؛ وهو يخصف نعله، فقال لي:

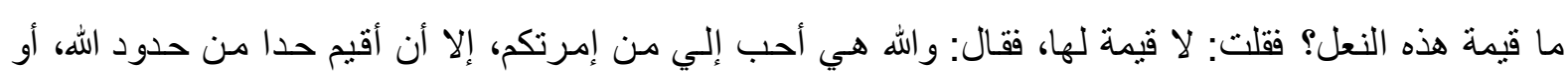

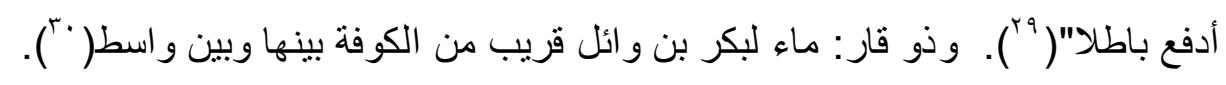

$$
\begin{aligned}
& \text { وتحدث بعدها عن الطيب في نقل عن دعبل الخزاعي، قال: } \\
& \text { لله لا لعطية أعطاها } \\
& \text { بأبي و أمي سبعة أحبهم } \\
& \text { و الطيبان وبنته و ابنتاها( ()'.). } \\
& \text { بأبي النبي حمح وصفيه }
\end{aligned}
$$

هو: دعبل بن علي بن رزين الخز اعي ولد سنة ^§ ا وتوفي سنة بـا هجرية

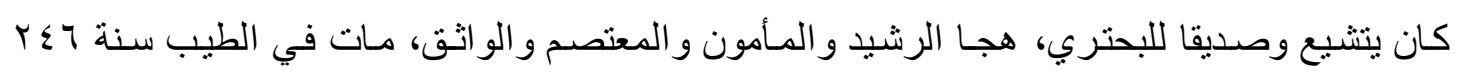
هجريـة، و الطيب: بليدة بين و اسط وخوزستان، و أهلها نبط، ولغتنهم نبطية.. بينها وبـين و اسط ثمانيـة عثـر

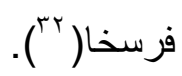

$$
\begin{aligned}
& \text { وتحدث عن قرية جرجاريا في نقل عن عصابة الجرجرائي: } \\
& \text { خو ان الأمير معمي المكان ل له شبح لبس بمستبان }
\end{aligned}
$$

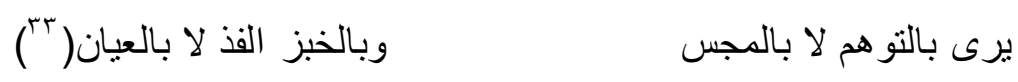

هو: إبر اهيم بن باذام من آهل جرجر ايا، لم نقف له على ترجمة، وقد ذكرنـاه لأنه من أهل هذه القريـة

مثلما يتبين من النقل.

$$
\text { وفي نقل ثان تحدث عن محمد بن الفضل الكاتب الجرجر ائي }
$$

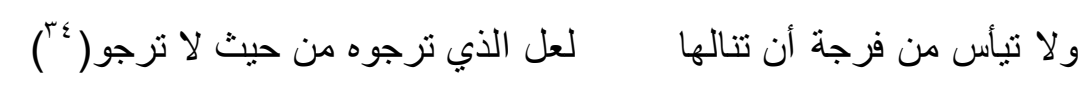

هو: محمد بن الفضل الجرجرائي، أبو جعفر الكاتب وزير المتوكل على الله، ثم المستعين العباسبين، كان قبل الوزارة يكتب للفضـل بن مروان. كـان ظريفا حسن الأدب عالمـا بالغنـاء لـهـ مـع إسحاق الموصلي أخبـار

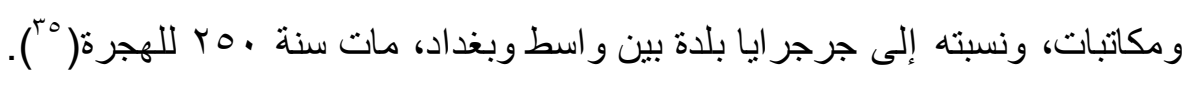
أمـا جرجاريـا فهي: بلد من أعمال النهروان الأسفل، بين واسط وبغداد، من الجانب الشرقي، كانت

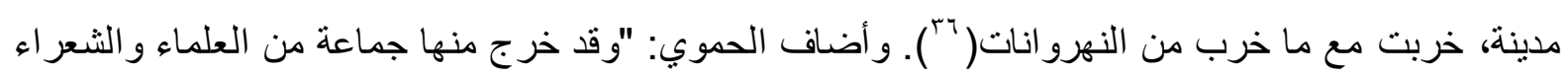

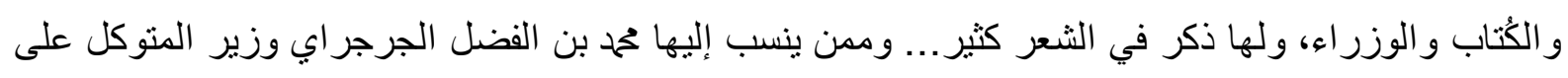

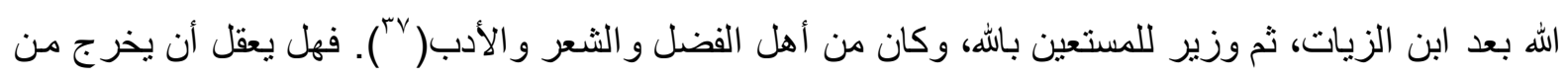
قرية من قرى واسط أو من القرى المجاورة لها مثل هؤلاء الأعلام، ولا تلد و واسط أفضل منهرج 
فضلا عن ذلك، تحدث الزمخشري عن قريـة لم يسمها في أثتاء نقله عن يونس بن حبيب، قال: قال

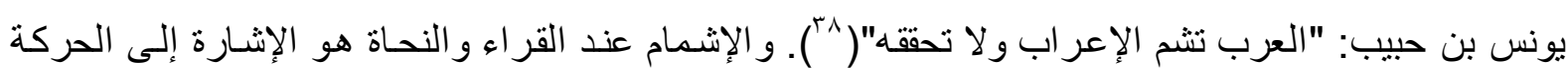
دون تصويب ورلا تحقق أي أنها تتركه دون توكيد أو إثبات.

هو: يونس بن حبيب الضبي البصري، أعجمي الأصل، من قرية على دجلة بين بغداد وو اسط عالم في الأدب، ولكن غلب عليـه النحو، احد أصـحاب عمرو بـن العـلاء، كانت لـه حلقة بالبصـرة أخذ عنـه الكسـائي

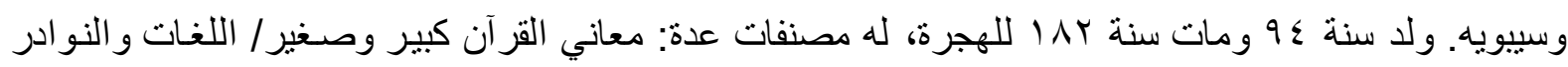

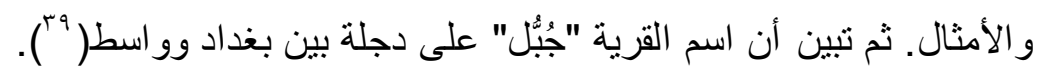
ومن قرى واسط التي ذكر ها الزمخشري عندما نقل عن ابن هبيرة قولا للباغندي، قال: قال ابن هبيرة:

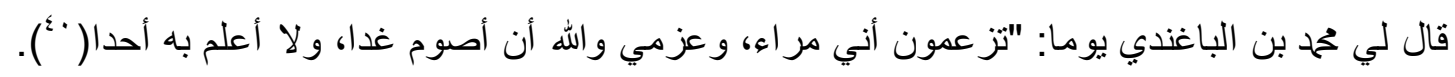
هو: أبو بكر محمد بن سليمان بن الحارث الباغندي الواسطي، هكذا ذكره الزمخشري، وهكذا ورد اسمه

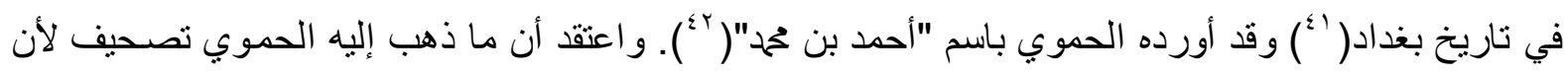

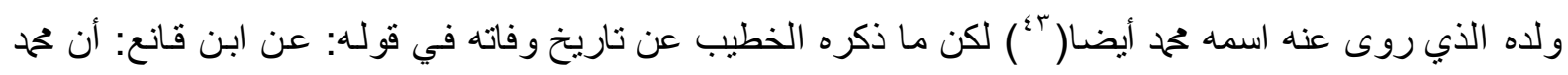

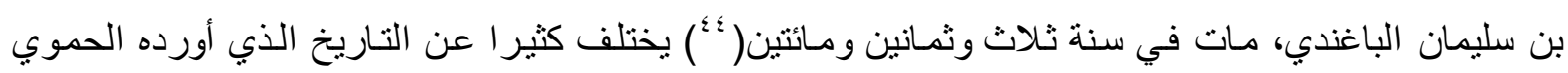
بقوله: "توفي سنة ب اس للهجرة"( ") )، أي بعد عقدين من الزمن، بما بعني أن هناك خلطا وقع بينه وبين ابنه. و الباغندي: نسبة إلى باغند، قال البغدادي: كأنها من قرى و اسط(" ؛)، وقال الحموي: أظنها من قرى

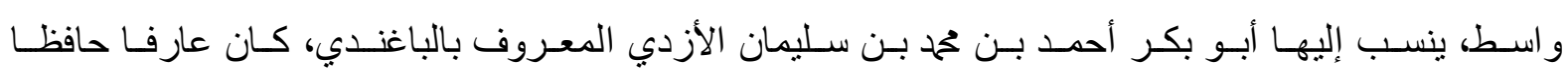

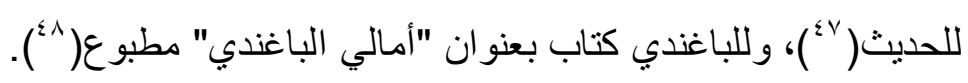
وفي نقله عن أحمد بن إبر اهيم العبرتاني، قال: قال العبرتاني:

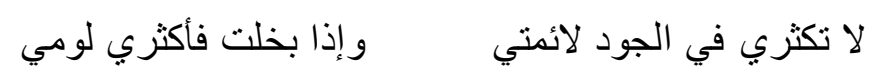

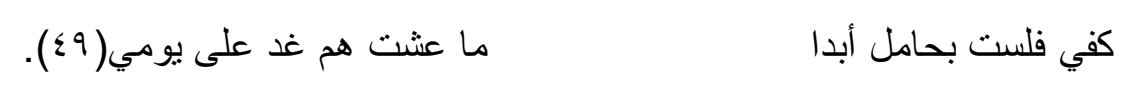

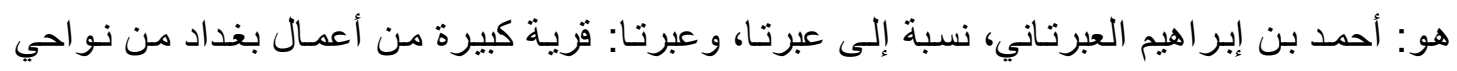

النهروان بين بغداد وو اسط، وقد نسب إليها من الرواة و الأدباء خلق كثير ( •).

وقال الزمخشري: قال هردان العليمي دليل يزيد بن المهلب حين هرب من السجن:

$$
\begin{aligned}
& \text { وجدت يزيد دون ما كان بزعم } \\
& \text { وسوء ظني بالأخلة أنني }
\end{aligned}
$$

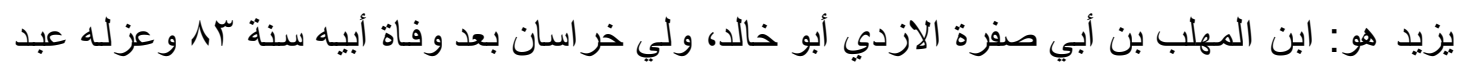
الملك بعد ست سنين، كان الحجاج يخشى بأسه. ولد سنة به هجرية، وقتل في العقر سنة ب • 1 هجريـة. و العقر: هو القصر الذي يكون معتمدا لأهل القرية، وهو عدة مو اضع، منها عقر السدن: من قرى الشرطة، بين بغداد

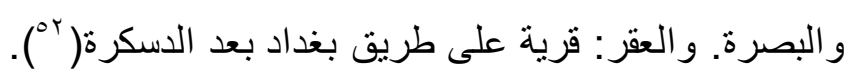


أما هُردان العُيلِّي فهو: شامي دمشقي. وهو دليل يزيد بن المهلب إلى العراق حين هرب من سجن

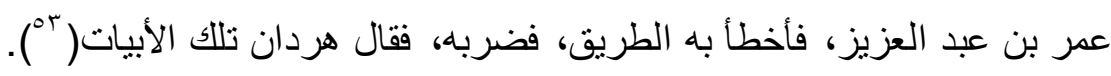

و هكذا تجد خلقا كثير ا من العلماء والأدباء و الوزر اء ينسبون إلى قرى واسطية أو مجاورة لو اسط، و لا

تجد من يُنسب إلى واسط في كتاب ربيع الأبر ار إلا قلة لا تكاد تذكر! ويبدو لي أن لذلك عدة أسباب منها: أن المدينة بناها الحجاج سيء الصيت و السمعة، المخلص للأمويين، مما جعل البعض يتحرجون من الانتساب إليها. فضلا عن ذلك أدت سيطرة العباسيين على مقاليد الحكم وسعيهم لمسح وطمر آثار الأمويين إلى إهمال المدينة من جهة، وخثية الناس من الانتساب إليها خوفا من بطش العباسيين من جهة أخرى!

\section{المهور الثالث- الوافدون واللاجئون وأهلها}

من بين ركام الأسماء التي وردت في كتاب ربيع الأبر ار، استخلصنا أسماء بعض أهل و اسط، وبعض من وفد إليها من غير ها، فأقام بها أو أدى عملا رسميا، أو لجأ إليها مجبر ا، وسنجد أن نسبة الو اسطيين منهم منخفضة جدا بشكل يجلب الانتباه، ولذا أخرت الحديث عن أهلها لأغر اض المقارنة و المقاربة. من الو افدين إليها هناك عدد كبير ممـن استوجب قدومهم إلى واسط لأمر يخص إدارة البلاد، أو لأغر اض التجـارة، أو مـرور كر ام، فموقعها الجغر افي جعلها موئلا لأصناف كثيرة من الناس، ومع ذللك لم يذكر الزمخشري إلا القليل، ومن هذا القليل بعض من وفد إليها، ومنهر:

سعيد بن جبير: سعيد بن جبير، عن ابن عباس: "الدنبا جمعة من جمع الآخرة، سبعة آلاف سنة، فقد مضى ستة

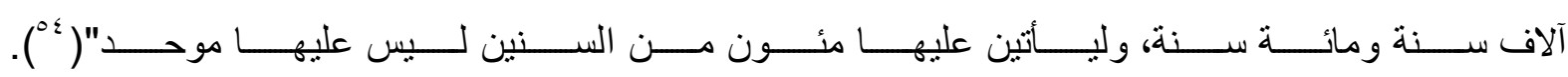
التابعي الكبير سعيد بن جبير (رضوان الله عليه) أشهر من أن نشغل أنفسنا بترجمته( (10)، وهو لم يفد إلي و اسط طائعسا، و إنما جيء بـه إليها بعد أن ألقي القبض عليـه بسبب اشتر اكه في ثورة ابن الأشـث؛ ليمثل بين يدي

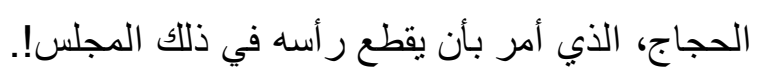

أبو معشر الفلكي: افتقدت امر أة أحد الكبار خاتمـا، فوجهت إلى أبي معشر، فقال: خـاتم الله أخذه.فتعجبت من قوله، ثم طلبته فوجدنه في أثناء ورق المصحف"("). أبو معشر: هو جعفر بن محمد بن عمر البلخي من أصحاب

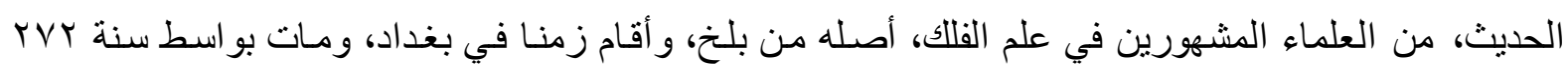
هجرية، وقد جاوز المائة

قتادة بن دعامة: قال قتادة: "بلغني أن رسول الله كان إذار أى الهلال قال: الحمد لله الذي ذهب بشهر كذاورجاء

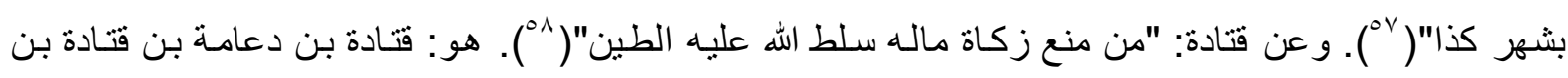

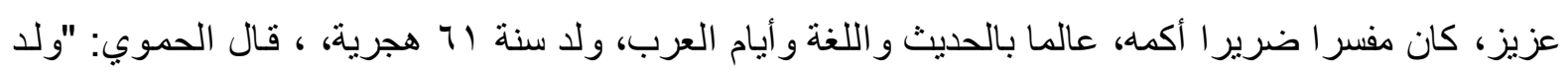

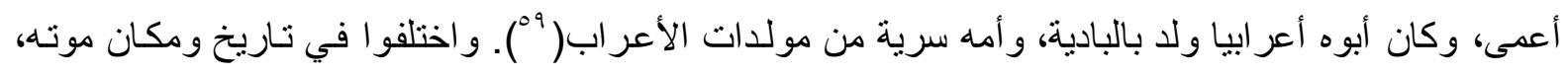

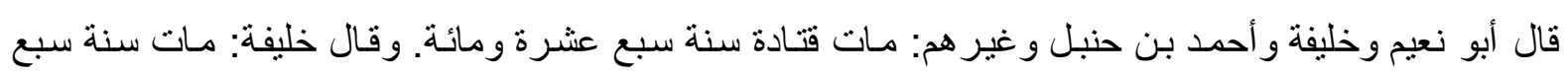

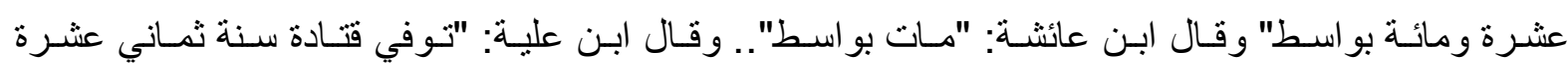

ومائة"( “). و قال ياقوت الحموي: "مات بالبصرة سنة سبع عشرة ومائة في أيام هشام بن عبد الملك"( ("). 
الوزير المهلبي: كان ابن قريعة القاضي في مجلس الوزير المهلبي فُوول رقعة فيها: ما يقول القاضي في رجل

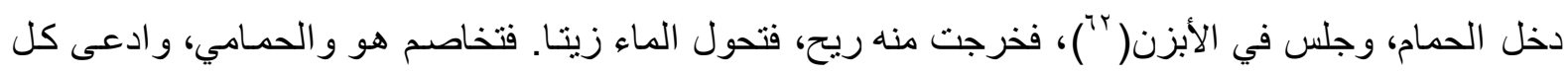

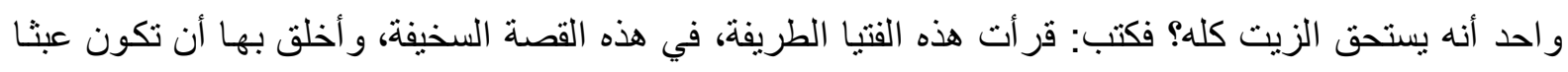

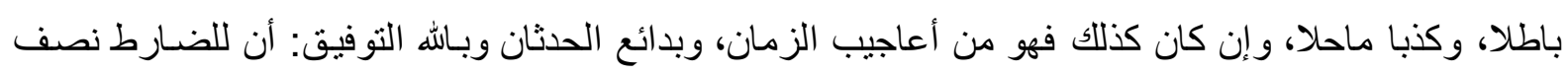

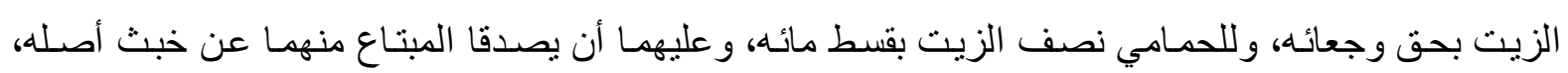

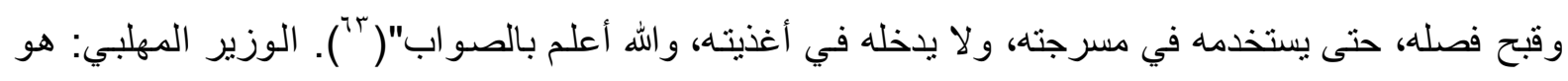
الحسن بن ححمد بن عبد الله بن هارون الملقب بذي الوزارتين: استوزره معز الدولة بن بويه، ثم المطيع العباسي،

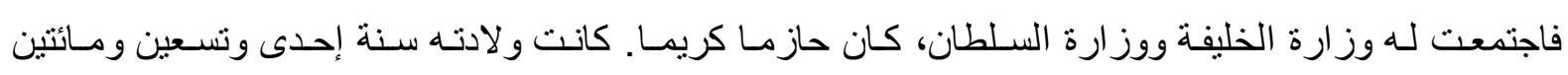
بالبصرة. وتوفي سنة اثتتين وخمسين وثلاثمائة في طريق واسط، وحمل إلى بغداد، ودفن في مقابر قريش( علي بن ححم الورزنيني: قال علي بن محم الورزنيني صاحب الزنج، لما هرب من داره؛ في اليوم الذي قتل فيه:

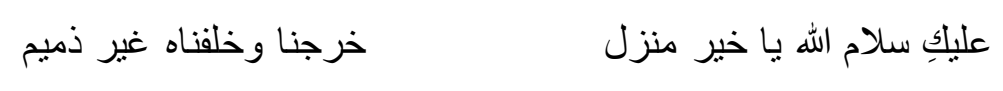$$
\text { فإن تكن الأيام أحثثن فرقة فما أحد من رييها بسليم( }
$$

علي بن ححمد الورزنيني: هو صاحب الزنج قيل: هو علي بن ححم بن عبد الرحيم، وقيل: هو علي بن عبد الرحيم، وقيل: هو علي بن محمد بن أحمد الحسني العلوي الطالبي، وقد أوغل مؤرخو الدولة العباسية في

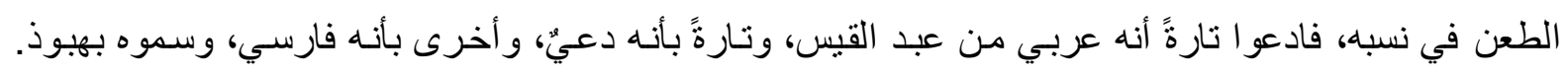

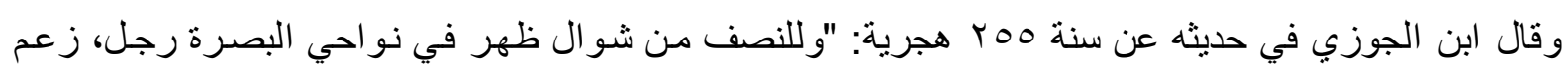
أنه علي بن ححمد بن أحمد بن علي بن عيسى بن زيد بن علي بن الحسين بن علي بن أبي طالب، وكان يقول: إن فئ

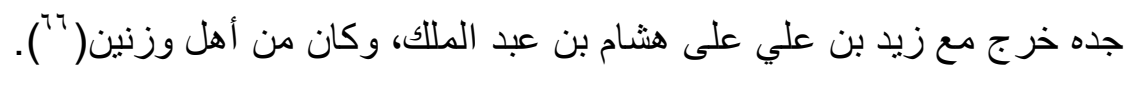
خرج علي بن حمح في أيسام المهتدي العباسي سنة ب00 فالتق حوله أهل البصرة وغيرهم، واستولى

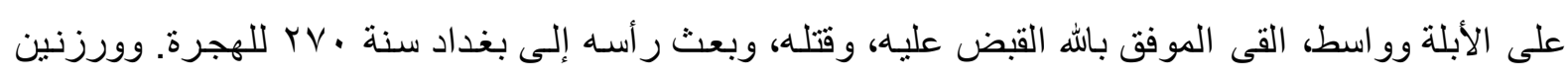

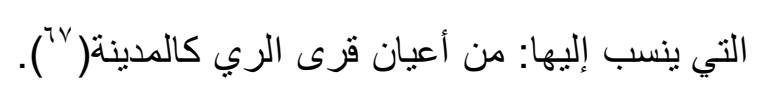
إن حديث المؤرخين المتناقض و الغريب عن هذه الثخصبة الثائرة التي خرجت على حكام الجور العباسيين كان غير مستقيم بـالمرة، فهو مبني على الظن و الاجتهاد لأسباب معروفة غايتها التشويه و التشـهير و الدفاع عن الحكام ومحاباتهم، و هذا ينبئك بنوع التحريف الذي تعرض لله تاريخنا بمجمله، بما يؤكد أن سرقة فئة ألق و اسط من قبل العباسيين و الموظفين لديهم لم يكن أمرا مستبعدا. السيد الحميري: قال الزمخشري: تزوج السيد الحميري بينت الفجاءة واتفاقهما عمر هما(^). هو شيعي، وهي

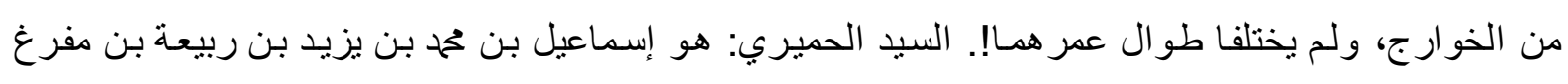

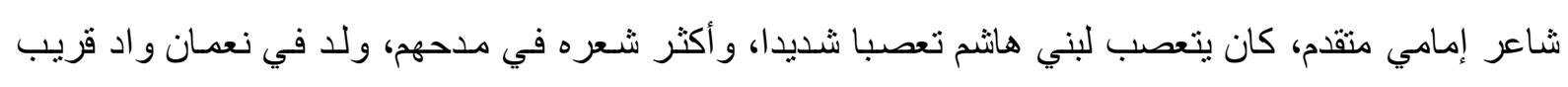

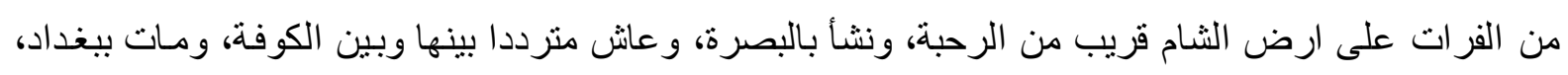


وقبل بو اسط("79.) ولذا أشكك كثبر ا بما أورده الزمخشري عنه، لسبب بسبطو هو أن السبد الحميري وصف بأوصـاف لا يستقيم معها أن يتزوج بخارجيـة من الخوارج، إذ وصفه الذهبي بأنسه: "من فحول الثـعر اء، لكنه

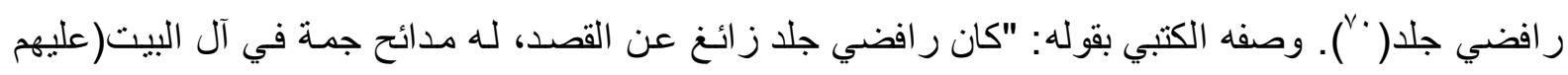
السلام)"( (2) (2)

شريك بن عبد الله: قال: "إنما الرجل بإخو انه، فإذا ذهب إخوان الرجل ذهب الرجل"(("). هو: شريك بن عبد الله

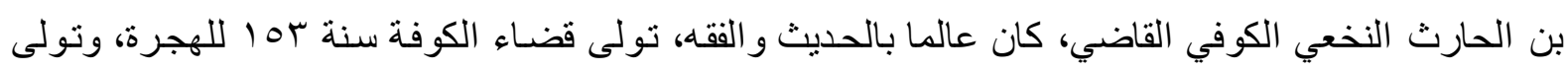

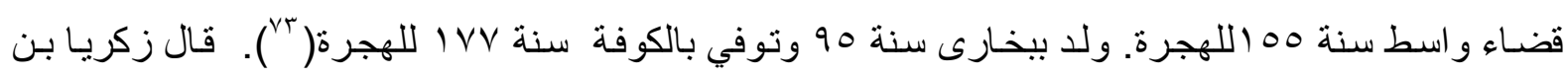
يحيى: لما قدم شريك إلى و اسط، نزل على عبد الرحمن بن حكيم، وذلك سنة خمسين ومائة.. وكتب عنه إسحاق ويزيد و أصحابنا الو اسطيون(

طلق بن حبيب: قال طلق بن حبيب: "في زبور داود: إن كنت لابد نسأل عبادي، فسل معـادن الخير ترجع

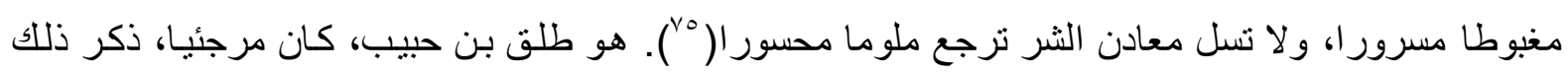

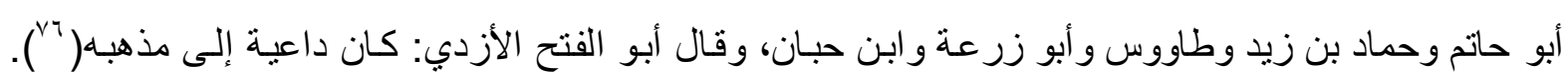

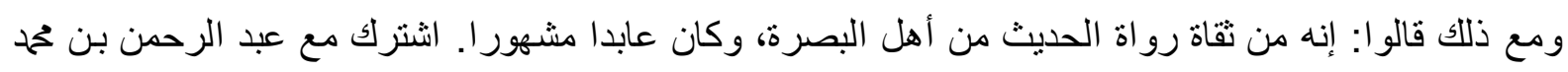
بن الأشعث في خروجه على الحجاج. وقر أت لحبيب بن أبي ثابت قوله الذي استوقفني كثير ا: "كنت مع طلق بن عن حبيب، وهو مكبل بالحديد حين جيء به إلى الحجاج مع سعيد بن جبير، ويقال إنه أخرج من سجن الحجـاج بعد موته، وتوفي بعد ذلك بو اسط(). وفي هذا القول دلالة على الانتقائية التي كانت تتحكم بمصسئر الأمسة وتاريخها، حيث ذبح الحجاج سعيدا، وسجن طلق لأسباب معروفة( (vv). أما ابن كثير فادعى أن القسري بعث من مكة ثنلاثة

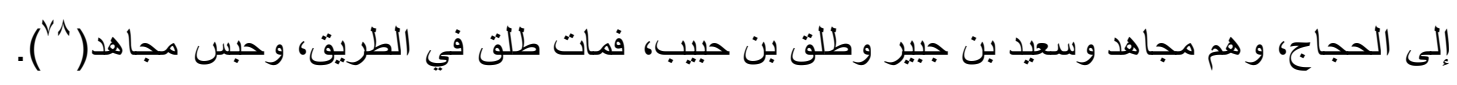
معاوية بن يزيد المهلبي: مر يزيد بن المهلب عند خروجه من سجن عمر بن عبد العزيز بأعر ابية، فذبحت لـه

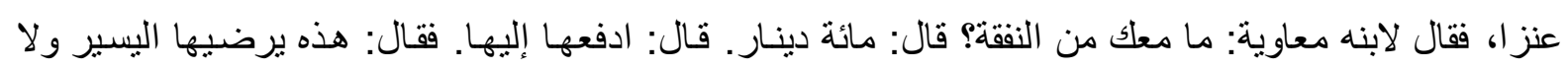

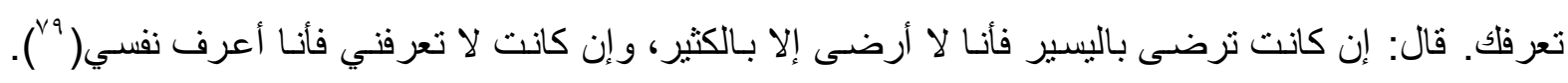
هو: معاوية بن يزيد بن المهلب بن أبي صفرة، كان من قو اد أبيه حين ولي خر اسان. استخلفه أبوه على سمرقند

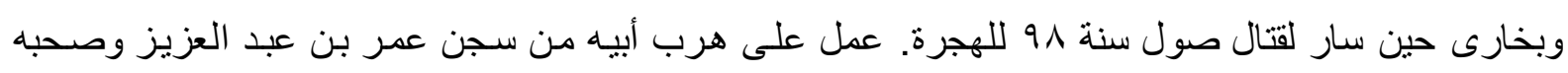
إلى البصرة، كما استخلفه أبوه على واسط حين أر اد الثخوص إلى حرب مسلمة بن عبد الملك وجيش الثام سنة

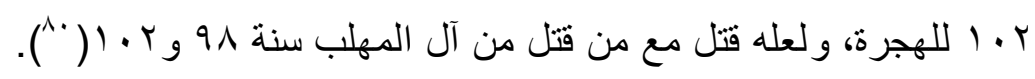
عدي بن ارطأة: كتب عدي بن ارطأة إلى عمر بن عبد العزيز: "إني احتفرت نهر الأهل البصرة عذب بـه

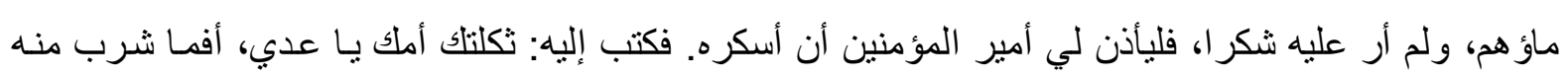

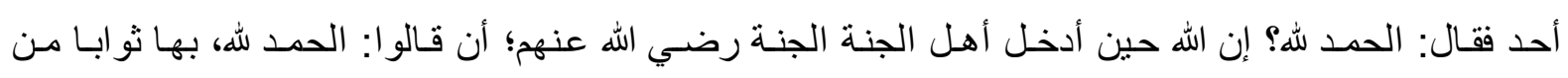
نهرك"('). هو: أبو و اثلة عدي بن ارطأة الفزاري، من أهل دمشق، قالو ا: إنه كان من العقلاء الثجعان، و ولاه

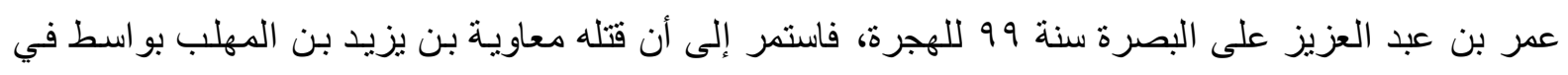


فتتة أبيه يزيد بالعر اق، وفي حديثه عن سنة تسع وتسعين قال ابن كثير : "وفي هذه السنة عزل عمر يزيد بن

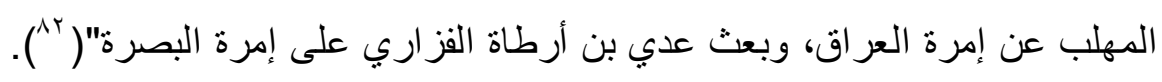

قال معمر: كتب عمر إلى عدي بن أرطاة: إنك غررتني بعمامتك السوداء، ومجالستلك القر اء، وقد

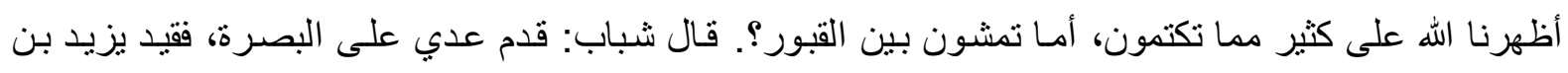

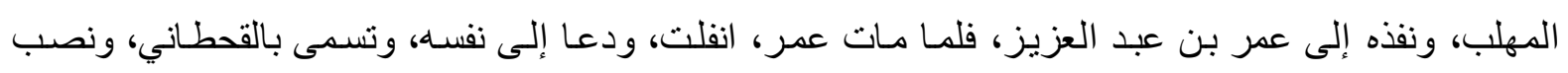

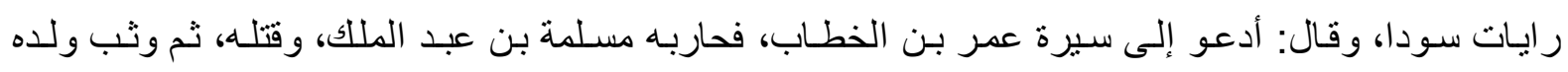

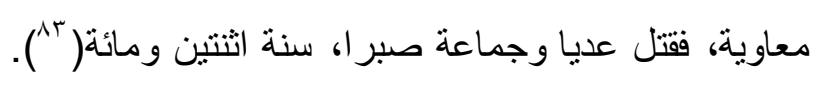

ومن اللاجئين إليها: الظاهر أن الذي دفع القائد البريطاني تاونزند إلى اللجوء إلى واسط، والتحصن فيها، بعد هزيمته في معركة المدائن ضد جيش الإمبر اطوريـة العثمانية، هو نفسه الذي دفع آخرين من قبل إلى اتخاذ و اسط حصنا للافاع عن أنفسهم وجيوشـهم، ربما بسبب موقعها الجغر افي وطبيعتها، حيث يحبط بها نهر دجلة من ثناث جهات، فهو سـاتر طبيعي، ليس من اليسير اختراقه، ولاسيما أيسام الفيضـان و أيسام الثتاء و الأمطار، ولكنه ممكن أن يكون فخا قاتلا في الوقت نفسه. و هناك في التاريخ عدة روايات عن قادة آخرين سبقو التاونزند إلى هذا الفعل، منهم يعقوب بن الليث. وعن ابن الليث هذا، قال الزمخثري: "لما أخذ يعقوب بن الليث محمد بن

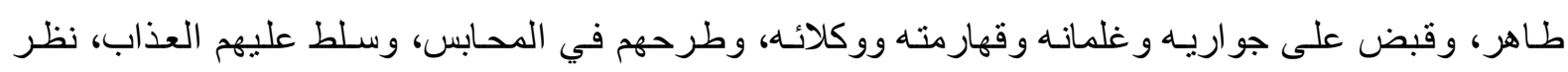

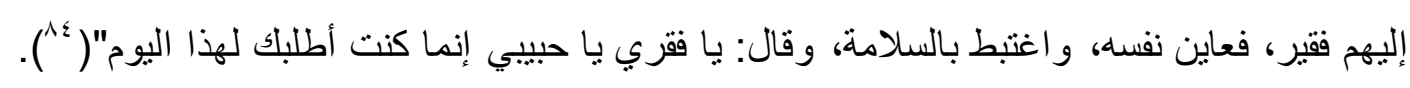
هو: يعقوب بن الليث الصفار، من الصفارين، كان في صغره يعدل الصفر، أحد الأمر اء الدهاة، كان

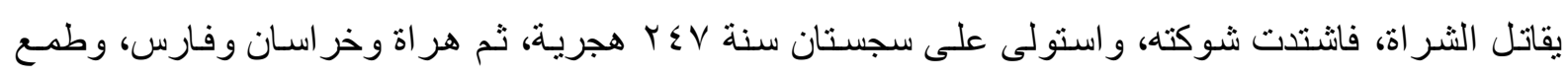

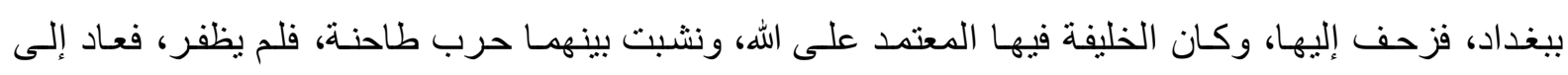

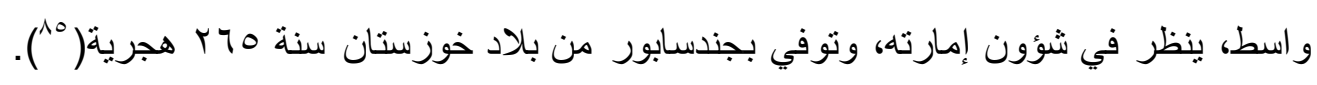
يزيد بن عمر بن هبيرة: أراد يزيد بن عمر قتل رجل، فضاقت عليه الأرض برحبها، فر أى في منامه من يقول:

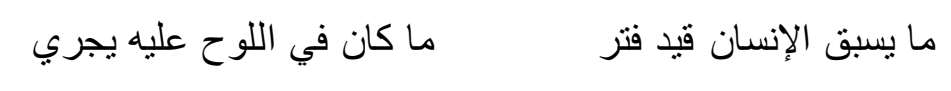$$
\text { فما أتى لذلك شهر حتى قتله أبو جعفر( (خ). }
$$

هو: يزيد بن عمر بن هبيرة الفزاري أبو خالد من أهل الثـام، ولد سنة NV للهجرة، ولي قنسرين

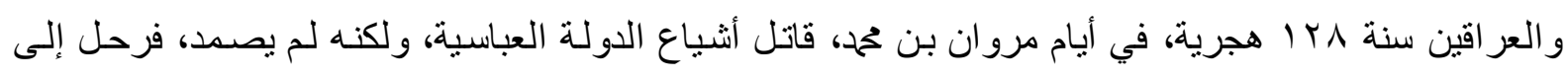
و اسط وحوصر بها، فوجه السفاح أخاه المنصور لحربه، فمكث المنصور زمنا بو اسط يقاتله، حتى أعباه أمره، فكتب إليه بالأمان و الصلح، فرضي ابن هبيرة، و أقام بو اسط، ثم بعث إليه السفاح من قتله بقصر و اسط سنة

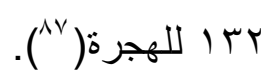

رجال من أهلها: ومن بين هذه القلة، تجد أسماء بعض الواسطيين الحقيقيين، لا تتجاوز عدد أصابع اليدين، وهذا

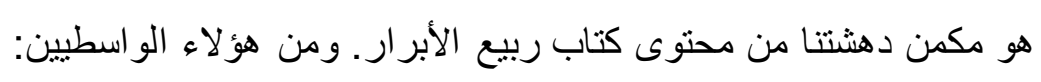

\section{$-\varepsilon \mid \varepsilon$.}


محمد بن يحيى الو اسطي: قال الزمخشري: قال محمد بن يحيى الواسطي: "ما عرف الله حق معرفته من آثر طاعة

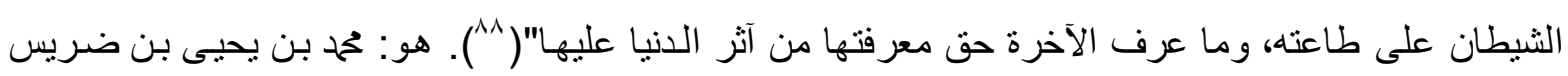
الواسطي، من رجال القرن الثالث الهجري، كان من رجال الحديث رواه بسنده عن رسول الله. أورده بحشّل تحت عنو ان: "الذي اتصل بنا ممن حدث عن أنس بن ماللك من أهل و اسط"( العو ام بن حوشب: قال: " أدركت من أدرك صدر هذه الأمـة يقولون: حدثو النـاس بمحاسن اصحاب ححم رسول

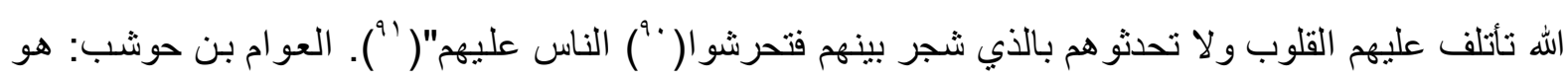

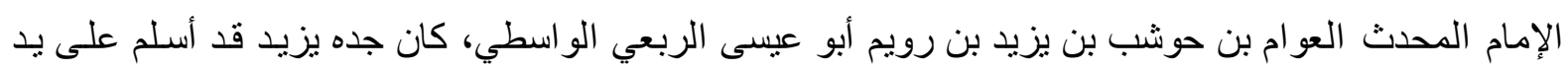

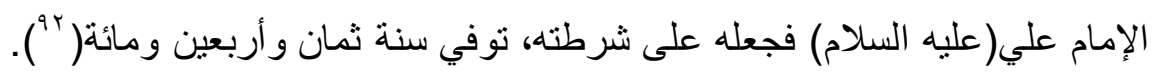
هثيم بن بشير الواسطي: حدث المأمون عن هثيم يرفعه: إذا تزوج الرجل المر أة لدينها وجمالها كان فيها سَداد

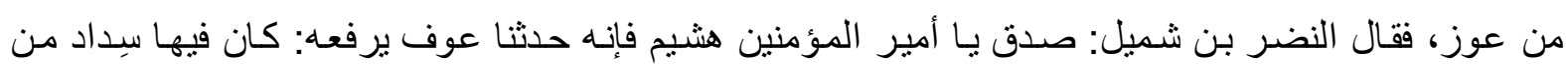
عوز، وكان المأمون متكئا فاستوى جالسـا، وقال: كيف قلت؟ قلت: الستَداد ههنا لحن، و إنمـا لحن هشيم وكان لحانه فتبع أمير المؤمنين لفظه، قال: أو تعرف العرب ذلك؟ قال: نعم، هذا العرجي يقول:

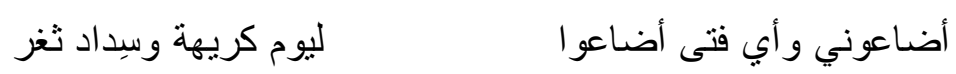

$$
\begin{aligned}
& \text { فقال: قبح الله من لا أدب له، ثم وصلني بخمسين ألفا(به). }
\end{aligned}
$$

هو: هُشيم بن بشير السُلمي، أبو معاوية الواسطي الحافظ، أحد الأعلام.. ولد سنة أربع ومائة( 9. هثام بن الحكم: قيل لهثام بن الحكم: "أترى الله في فضله و عداه وكرمه، كلفنا مـا لا نطيق ثم يعذبنا؟ قال: قد و الله فعل، ولكن لا نستطيع أن نتكلم"( (90). هو هشـام بـن الحكم، أبو تحمد الثيباني بـالولاء، ولـ بالكوفة، ونشـأ

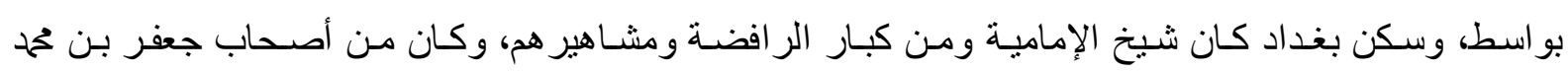

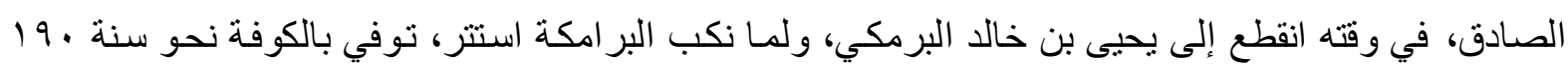
هجرية، ويقال إنه عاش إلى خلافة المأمون( عنبة الغلام: كان عتبة الغلام يدخل في الصلاة في مئزر فيخرج وقد تصبب عرقا فقيل له في ذلك، فقال: حياء من ربي( (ه)). هو عتبة بن أبان بن سمعة وقيل: صمعة الغلام، من أصحاب عبد الواحد بن زيد ويحيى الواسطي

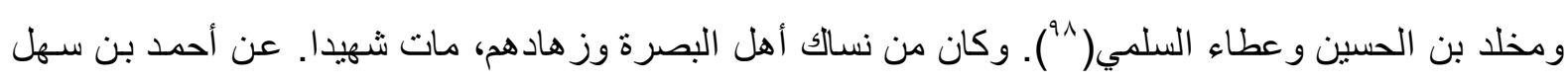

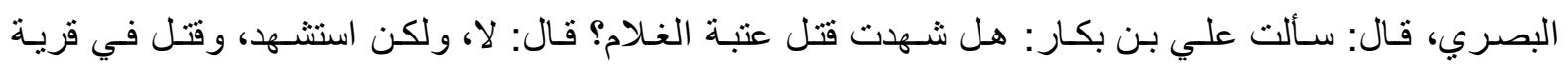

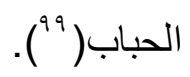

شعبة بـن الحجـاج: قـال ابن شبرمة في كرز بـن وبرة الحـارثي ومحمد بن طـارق، وكانسا أخوين في الله، وكانـا عابدين:

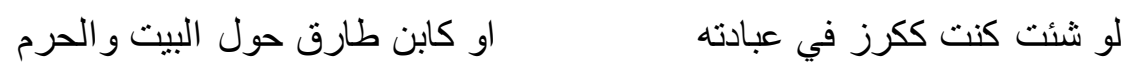




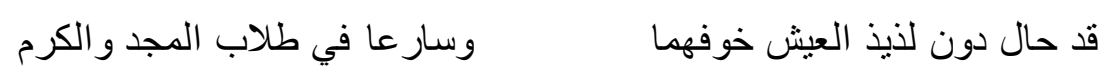

قال عبد الله بن المبارك: أنثـنهما شعبة حين قدمت البصرة، فاستعانيهما فقلت: أبـا بسطام مـا تصنع بهما؟ فقال: لو كنت في بين يشكر أو في الخريبة لجئنك فيها حتى اسمعهما(" '). هو: شعبة بن الحجاج بن الورد العتكي الأزدي، أبو بسطام، من رجال الحديث حفظا ورو اية وتتبيتا. ولد بواسط سنة بر للهجرة، وكان

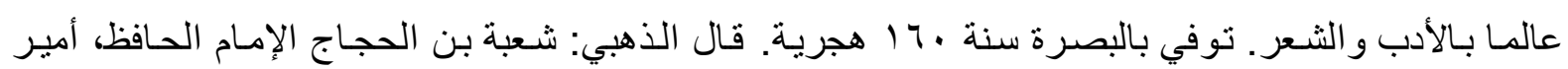
المؤمنين في الحديث، أبو بسطام الأزدي العتكي، مولاهم الو اسطي، عالم أهل البصرة وشيخها، سكن البصرة

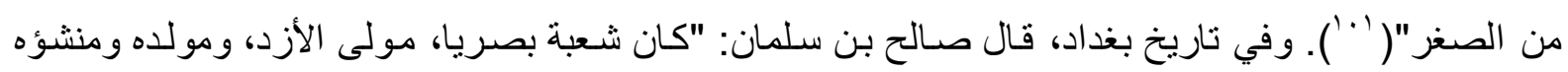

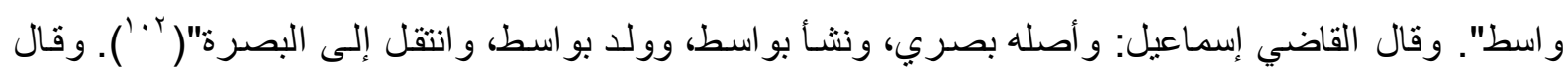

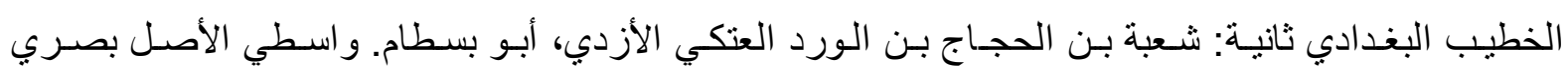

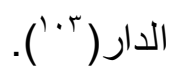

محم بن الحسن: عن ححمد بن الحسن: "كان أبو حنيفة واحد زمانه لو انشقت عنه الأرض لانشقت عن جبل من

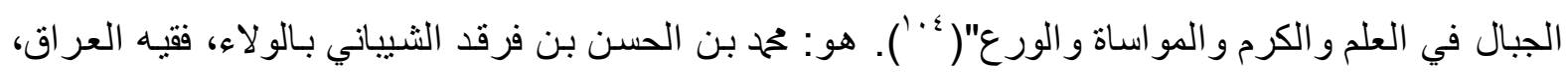

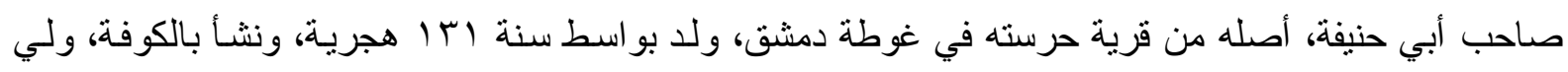

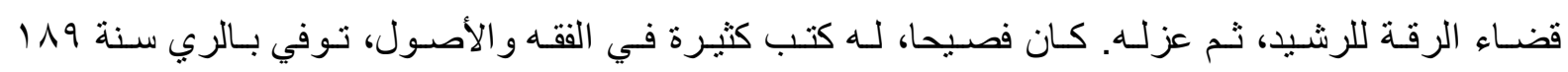

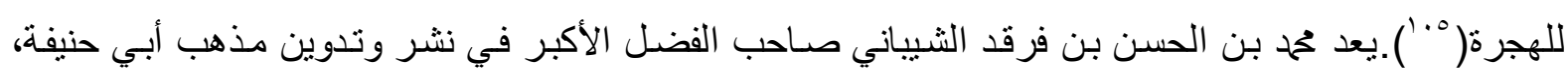
على الرغم من أنه لم يتتلمذ على شيخه أبي حنيفة إلا لمدة قصيرة جدا، و استكمل در استه على يد أبي يوسف،

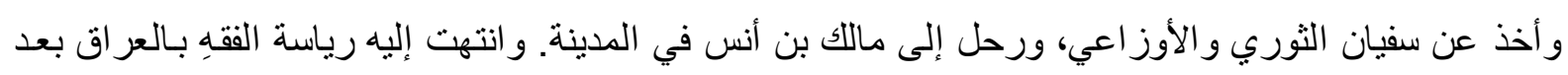

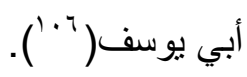

إبر اهيم بن ححمد بن عرفة المهلبي الواسطي: أورد له الزمخشري:

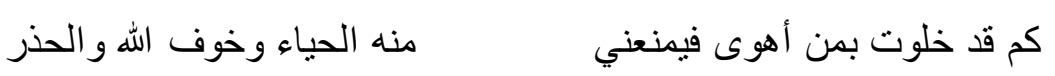

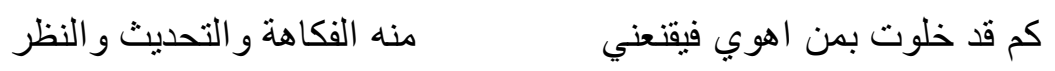

$$
\begin{aligned}
& \text { أهوى الملاح و أهوى أن أجالسهر ليس لي في حرام منهم وطر }
\end{aligned}
$$

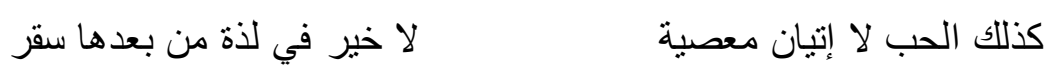

هو: إبر اهيم بن حمح بن عرفة بن سليمان بن المغيرة بن المهلب بن أبي صفرة الأزدي، أبو عبد الله،

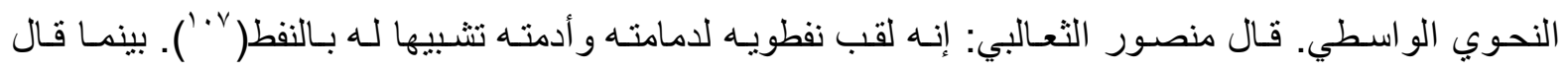

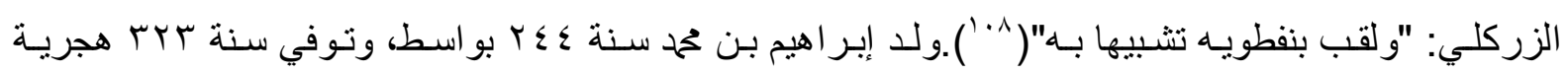
بيغداد، كان عالما بالعربية و اللغة و الحديث. سمى لله ابن النديم وياقوت عدة كتب منها: كتاب التاريخ وكتاب

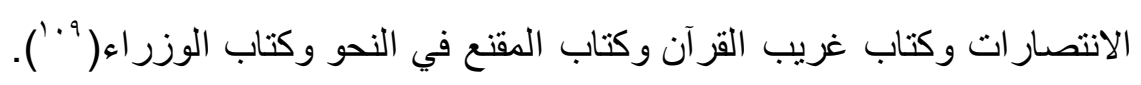


لم يورد الزمخشري في كتابه ربيع الأبرار؛ هذا السفر الكبير("'ل) سوى سبعة أقوال لسبعة من رجال

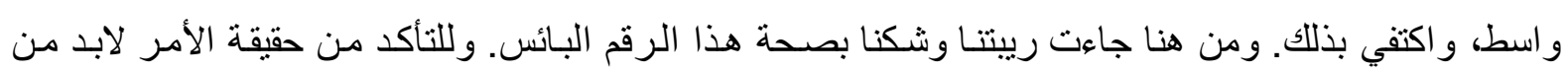
تقكيك المعطيات أدناه:

الأول: أن كتاب الزمخشري بمجمله، اعتمد على إير اد أقو ال و أحاديث مشهورة، ومن يكن هذا منهجه، لا يلتقت إلى أصل و عقيدة القائل، بقدر التفاته إلى مو ائمة القول المقتبس للفئة التي يضاف إليها، و الباب الذي يدخل فيه،

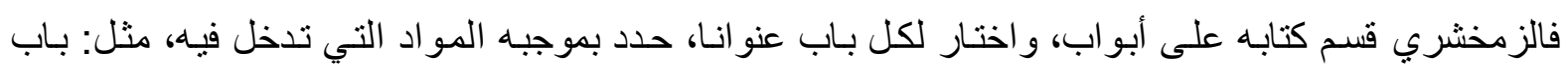

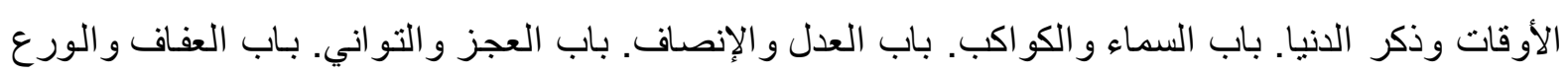
و العصمة. باب الظن و الفر اسة. ولا أعتقد أن فئة من فئات المسلمين خلت من وجود رجال لهم أقو ال تتاسب هذه الأبو اب.

الثاني: أن و اسط ومنـذ الأيسام الأولى لو لادتها أنتجـت و أنجبت قامسات باسقة مـن العلمـاء و الحكمـاء و الثـعر اء ورجال التفسير و الحديث و اللغة والنحو، وقد ملأ ذكر هم، وعاطر سيرتهم بطون كتب التاريخ و التفسير والحديث

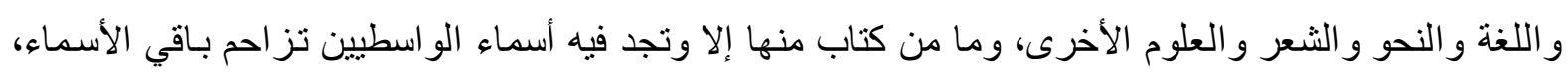

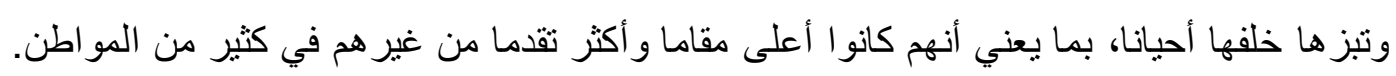
الثالث: أن الزمخشري الذي ولد بزمخشر من قرى خوارزم('"') في رجب سنة لآـ هجرية، كان قد قدم

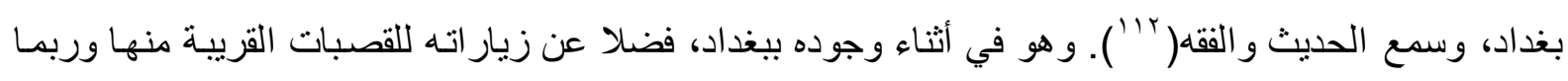
كانت و اسط من ضمنها، سـع الكثير مـن أقو ال العر اقيين من بصريين وكوفيين وو اسطيين وبغداديين، وقد اختار من تللك الأقو ال ما يناسب أبو اب كتابه، فأضافها إليه؛ دون أن يتحيز إلى مدينة، أو بنحاز عن أخرى. وفق هذه المعطيات من المفروض أن تكون لواسط حصتها في كتـاب ربيع الأبرار، ومـن المنطق

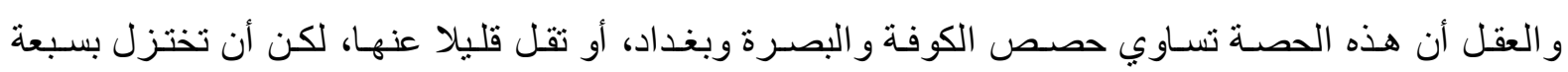
أنخاص فحسب، فذلك جالب للثك، ودافع للريبة، ولابد و أن تكون هناك قصدية مبيتة ور اء تغييب ذكر هم.

وهنـا نـرى مرة أن الزمخشري مرشّح لفعل ذللك لعدة أسباب، منها: الأول: أنه كـان متحيز العقيدته ومدافعا عنها، ومن خلال ذلك حاول التركيز على من هم أقرب إلى منهجه من غيرهم، في وقت اختار فيه

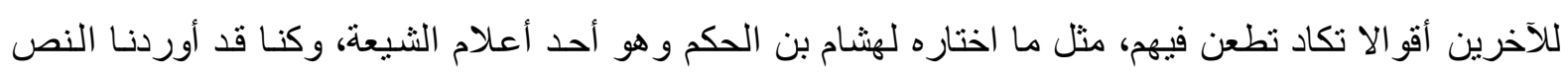
من قبل، ونعيد ذكره هنا ليكون دليلا: قيل لهشام بن الحكم: "أنرى الله في فضله وعداه وكرمه، كلفنا ما لا نطيق

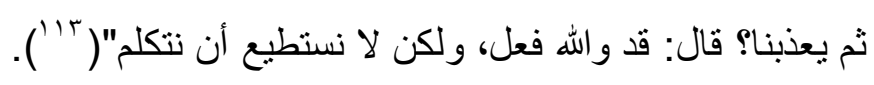
الثاني: ما ورد على لسـان الذين وصفوه، وفي ذلك إثـار ات إلى تحيز الرجل، إذ وصفه الزركلي بأنه: "كان

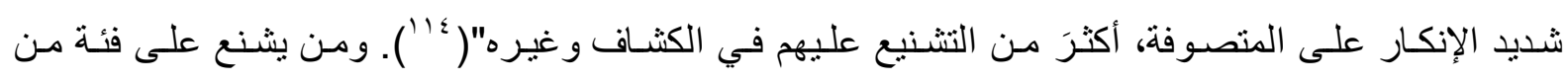
المسلمين ممكن أن يغمط فئة أخرى حقها. الثالث: أن أغلب أهل و اسطو على مر التاريخ كانو ا إما شيعة أو من أتباع أبي حنيفة النعمان. 
ومرة أخرى، يأخذنا الثك إلى اتهام السياسيين، فالمعروف أن العباسيين عملو ا على طمس ذكر كل مـا يمت للأمويين بما في ذلك. وقد يكون الزمخشري بريئا، فربما لم تكن له قصدية في الاختبار، و وان مـا نجده في الكتاب من قصدية سببه أن الكتاب، وقع مثنل غيره من نتاج الأقدمين بين أيسادٍ للئيـة، بدلت وغيرت ورفعت وخفضت فيه، و هي التي تسببت في حدوث هذا التبـاين، و هنـاك دلائل على وجود التلاعب، فـالمعروف أن الزمخشري توفي سـنة مبه للهجرة، بينمـا نجد في الكتـاب معلومـة عن فضـل الله العمري الثـافعي وكتابـه المسالك و المماللك، والعمري ولا سنة سبعمائة، وتوفي سنة V؟ للاهجرة، أي بعد قرنين من وفاة الزمخشري، و هذا لوحده يثبت وجود التلاعب، ويؤكد أن الكثير من كتب تاريخنا تعرضت إلى أنواع كثيرة من التحريف لأسباب سياسية ومذهبية و عصبية. وتبقى الأقو ال في سبب تغييب رجال واسط في كتاب ربيع الأبر ار مجرد احتمالات وظنون وتوقعات، يرقى بعضها إلى اليقين، بمـا يعني أن الموضوع يحتاج إلى در اسـة أكاديمية جادة نظر ا لعلاقته بكل المماحكات التاريخية، ولاسيما ما حدث بعد التغيير في r ...T، فما حدث لم يكن وليد سـاعته بقدر كونه نابعا من مواريث الفرق وتر اثها.

الهواهش

ا ينظر: عبيدات، ذوقـان، البحث العلمي مفهومـه و أدو اتهـ وأسـالييه، ذوقـان عبيدات، كايد عبدالحق، عبدالرحمن عدس ، دار الفكر، بيروت، $.1 \vee 70.191 \varepsilon$ r عريفج، سـامي، فـي منـاهج البحث العلمـي وأسـاليبه، سـامي عريفج، وخالد حسـين مصـلح، ومفيد نجيب حو اشـين، دار مجدلاوي للنشـر

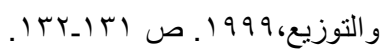
r قالو ا: و اسط في عدة مو اضع منها و اسط الحجاج... وقيل للعرب سبعة مو اضع يقال لكل واحد منها و واسط، منها و اسط نجد في شعر خداش بن زهير، وواسط الحجاز في شعر كُثَّرَ، وواسط الجزيرة في شعر الأخطل، وواسط اليمامة في شعر الأعشى، وواسط العراق، ولم يذكر الآخرين.

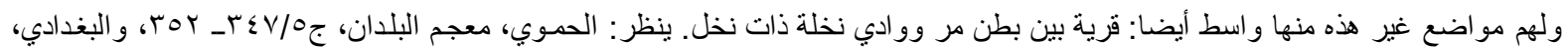

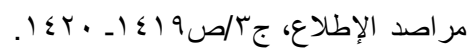

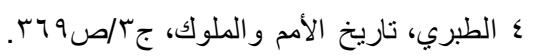

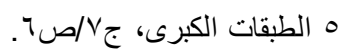

7 يقصد بالعسكرة أو العسكر اتية أن يكون للجيش دورا حاسما في تحديد السياسة العليا للبلاد. و تتحدد صور العسكرة و أشكالها حسب مدى هذا الدور ودرجة تأثثيره.

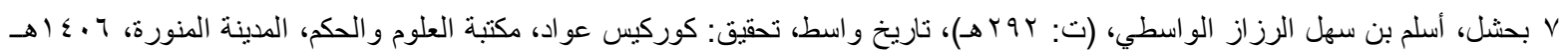

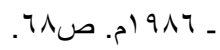

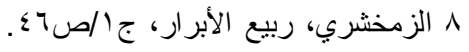
9 • 1 خوارزم: ناحية كبيرة عظيمة قصبتها الجرجانية، أهلها يسمونها كُركانج، و هي ولاية متصلة العمارة، منقاربـة القرى، كثيرة البيوت المفردة

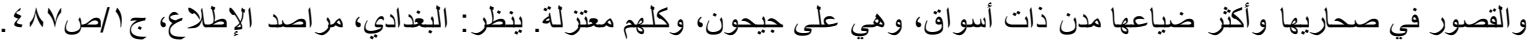
11

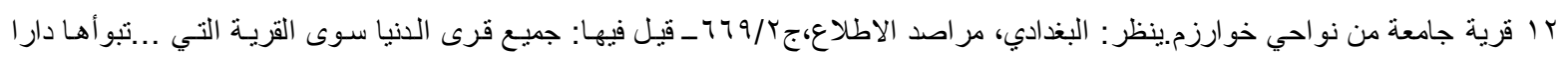
فِدِاء زمخشر ا.

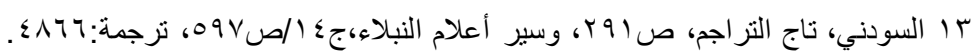

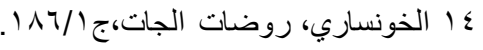

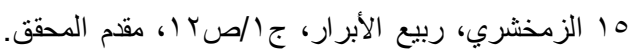




$$
\begin{aligned}
& 17 \text { سير أعلام النبلاء، جع (/ص7ه9 }
\end{aligned}
$$

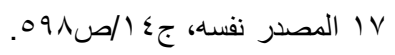

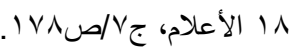

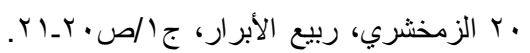

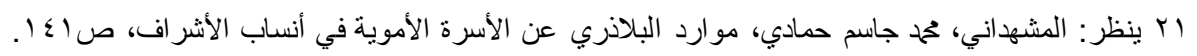

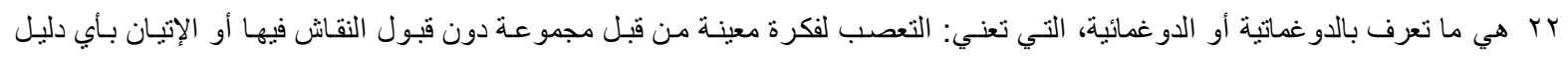

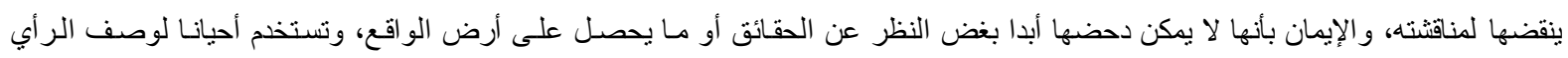

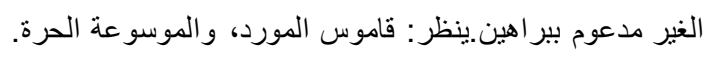

r ب ينظر : روزنتال، م. الموسوعة الفلسفية السوفيتية، وجميل صليبا، المعجم الفلسفي.

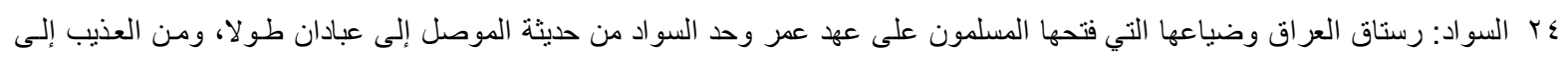
حلوان عرضا ro

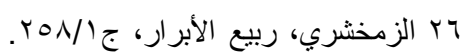

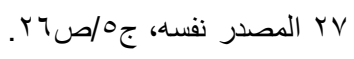

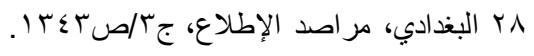

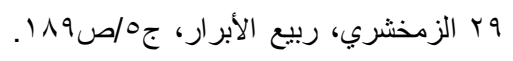

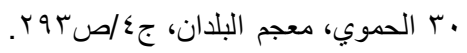

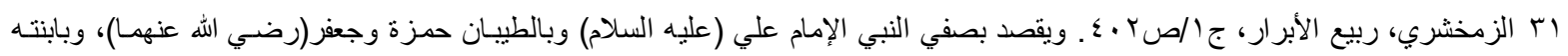

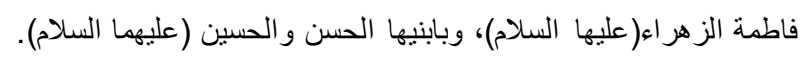

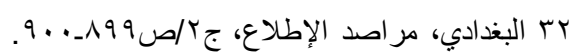

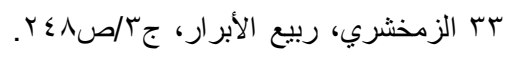

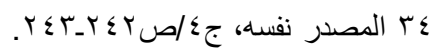

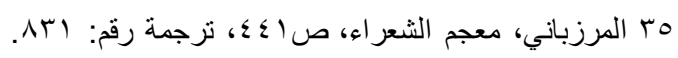

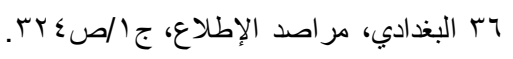

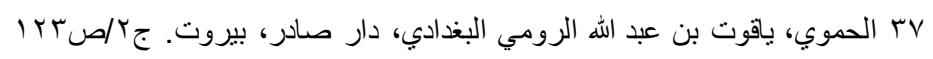

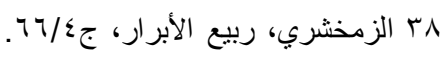

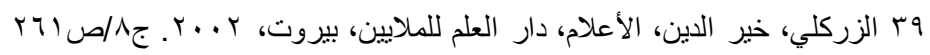

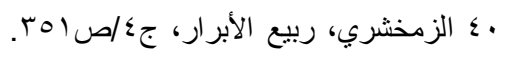

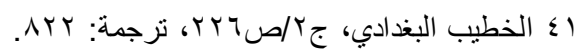
r

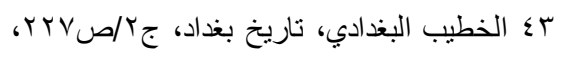
ع

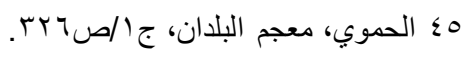

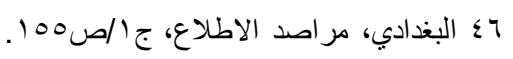

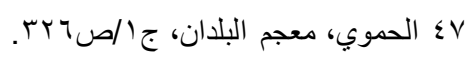

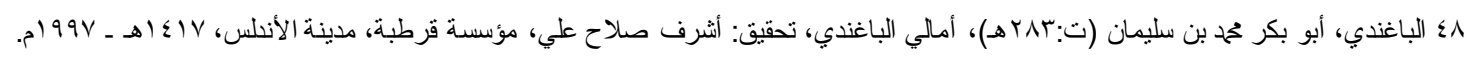

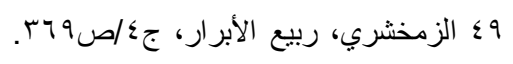

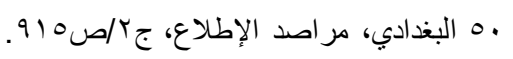




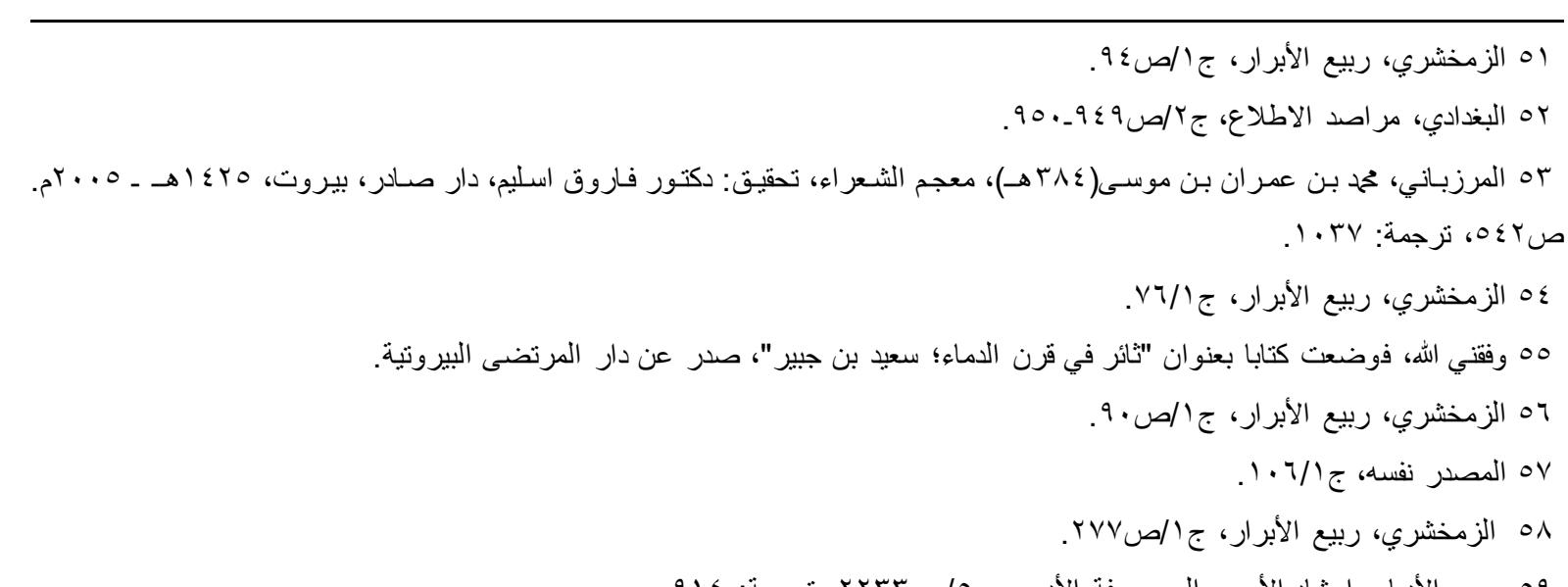

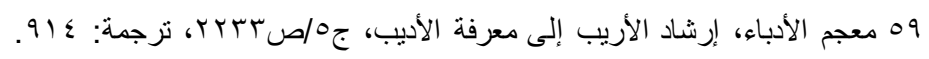

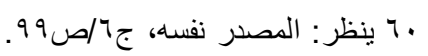

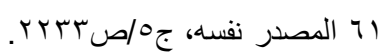

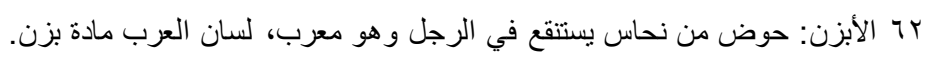

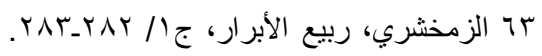

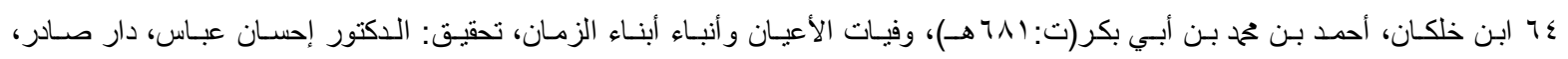

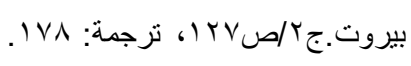

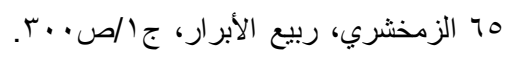

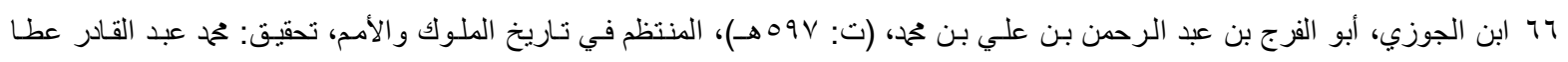

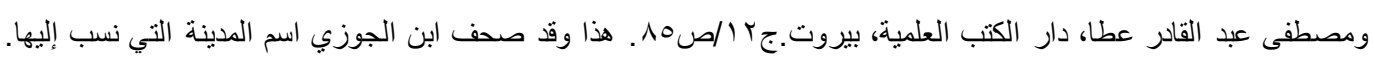

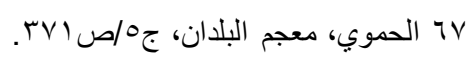

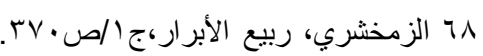

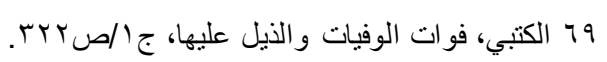

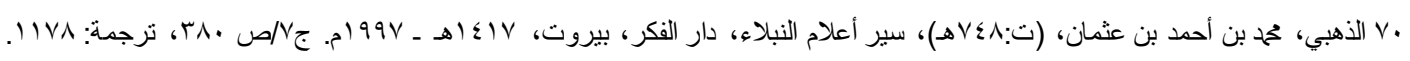

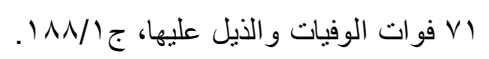

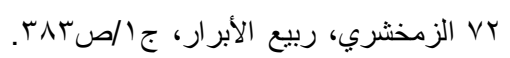

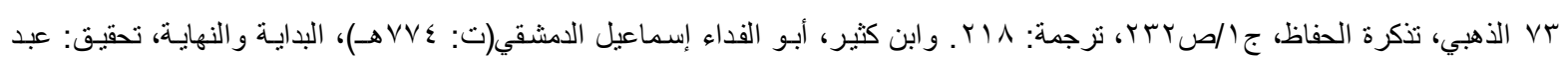

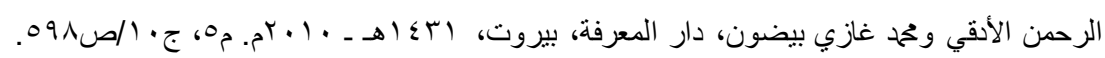

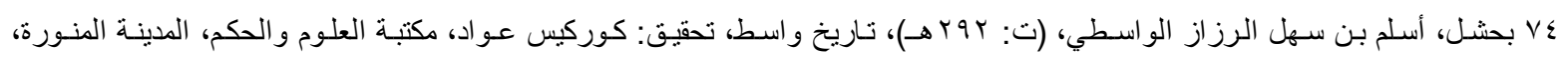

. T)

V To

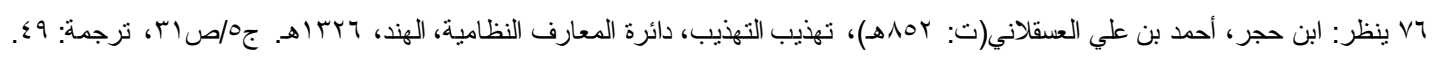

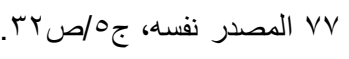

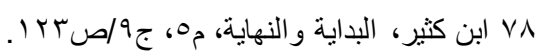

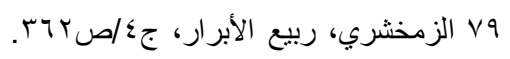

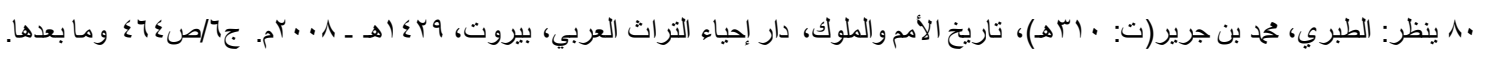

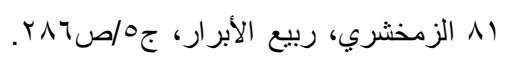

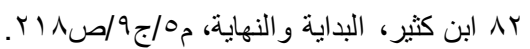

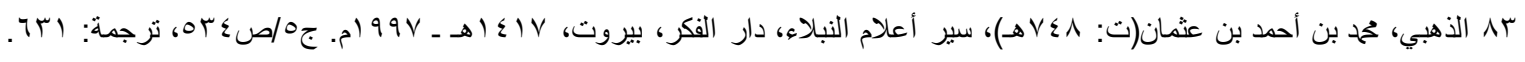

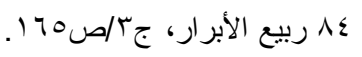

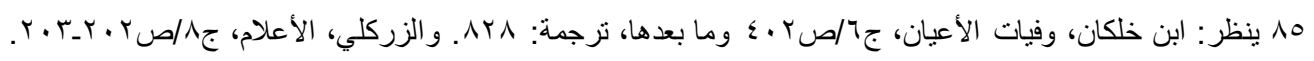

\section{- \& Y.}




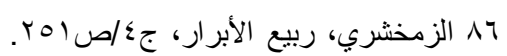

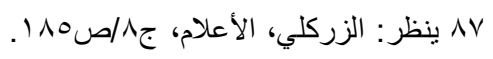

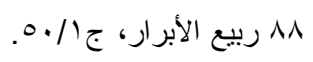

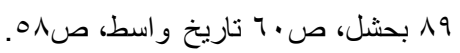

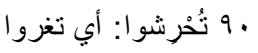

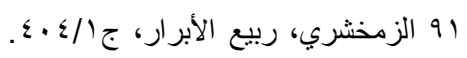

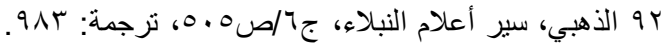

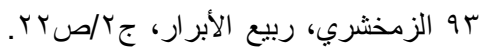

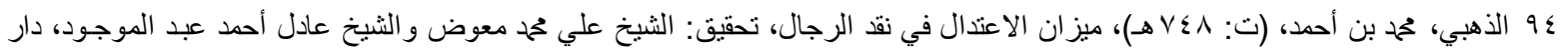

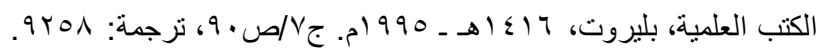

هو الزمخشري، ربيع الأبرار، جr/صهو.

ج9 ابن حجر، أحمد بن علي، (ت: بهـهـ)، لسان الميز ان، تحقيق: عبد الفتاح أبو غدة، مكتب المطبو عات الإسـلامية، ودار البشـائر الإسـلامية،

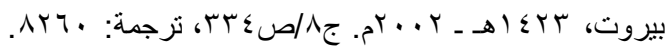

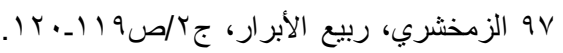

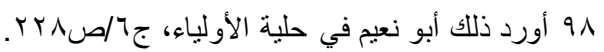

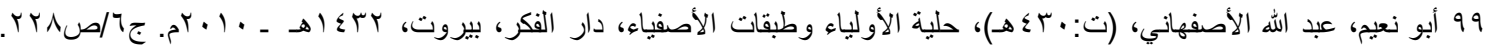

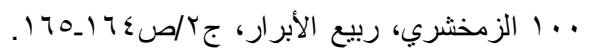

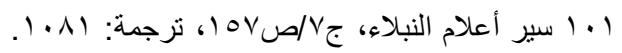

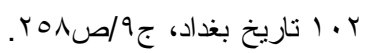

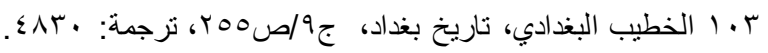

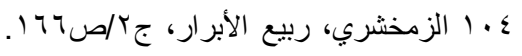

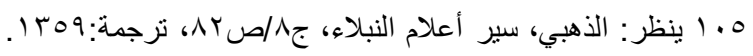

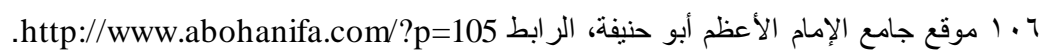

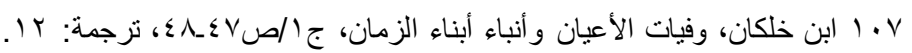

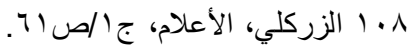

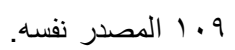

• 11 الكتاب في طبعته التي اعتمدناها في البحث، مكون من خمسة مجلدات كبيرة، صدرت عن مؤسسة الأعلمي للمطبو عات في بيروت.

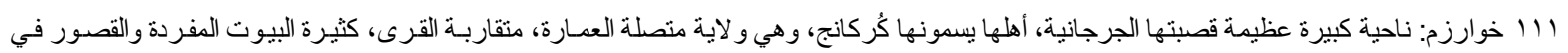

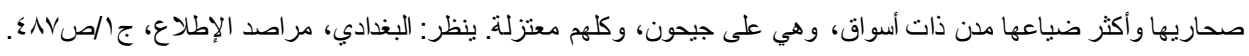

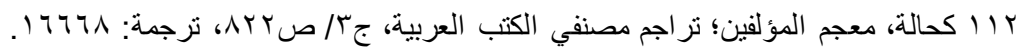

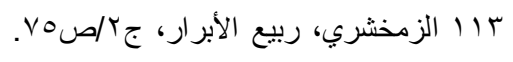

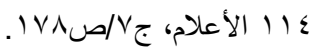

هصادر البحث

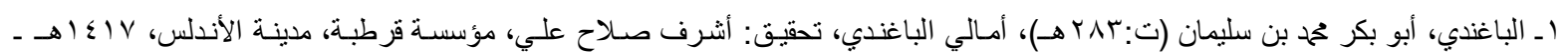

. $199 \mathrm{~V}$

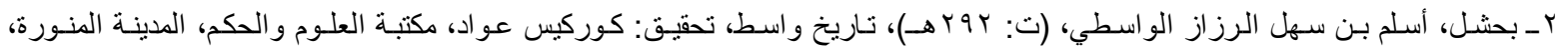

م) 917 - مـ

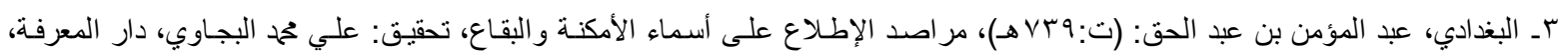


عـ ابن الجوزي، أبو الفرج بن عبد الرحمن بن علي بن محمد، (ت: هوهــ)، المنتظم في تـاريخ الملوك والأمم، تحقيق: حمحد عبد القادر عطل ومصطفى عبد القادر عطا، دار الكتب العلمية، بيروت، (د.ت). ـ الحموي، ياقوت بن عبد الله الرومي البغدادي،

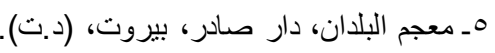

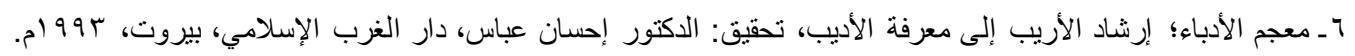

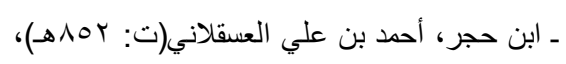

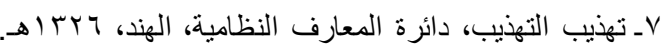

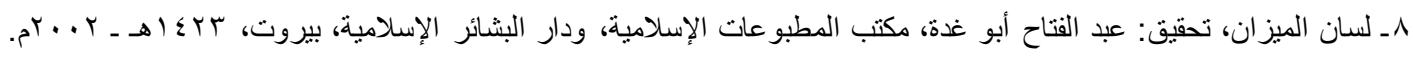

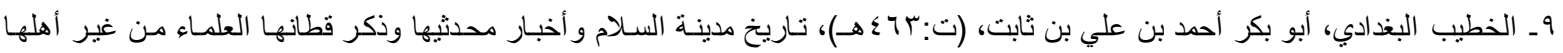

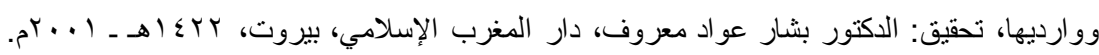

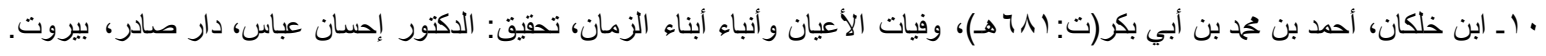

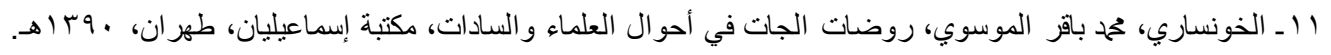

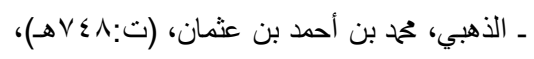

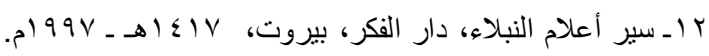

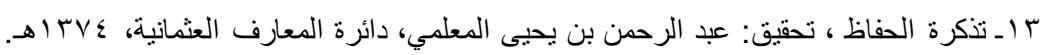

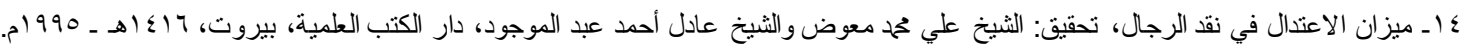

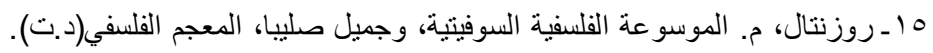

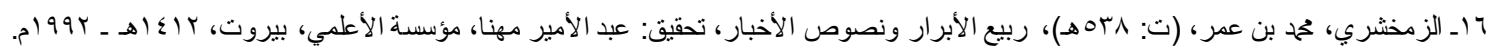

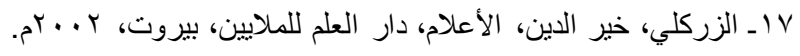

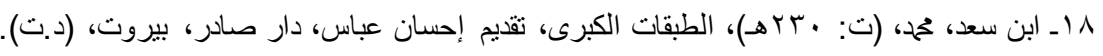

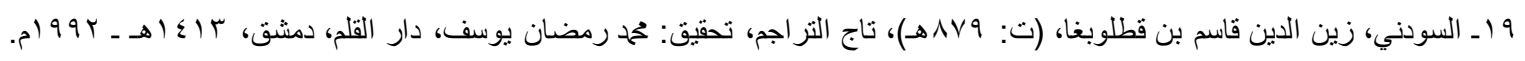

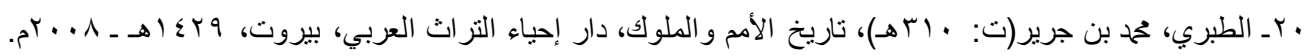

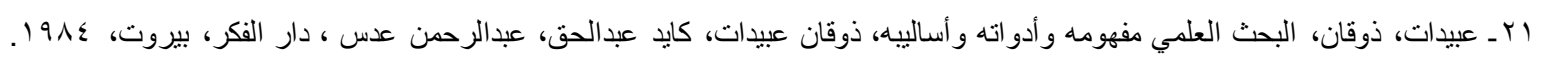

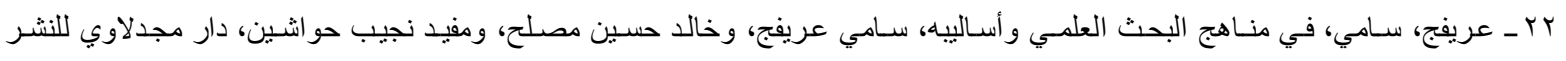

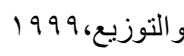

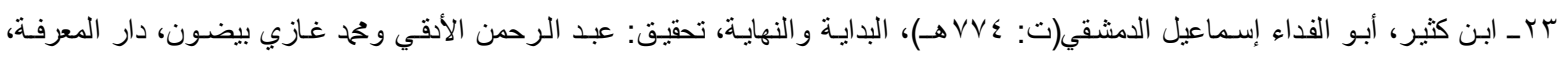

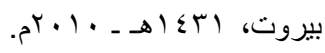

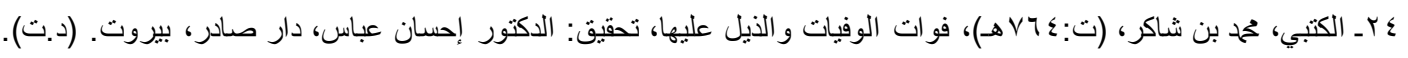

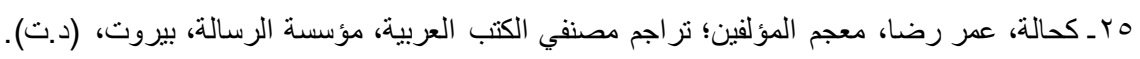

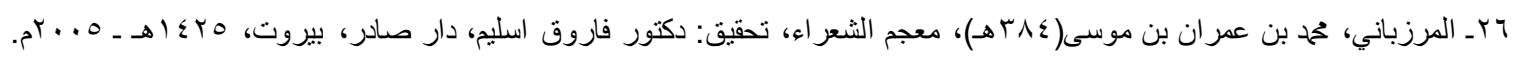

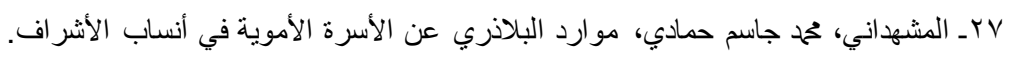

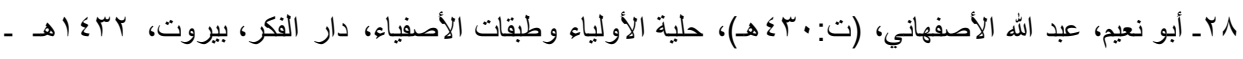
9 ـ ـ موقع جامع الإمام الأعظم أبو حنيفة على شبكة الانترنيت 